University of Florida Levin College of Law

UF Law Scholarship Repository

UF Law Faculty Publications

Faculty Scholarship

2020

\title{
How the COVID-19 Pandemic Has and Should Reshape the American Safety Net
}

Andrew Hammond

University of Florida Levin College of Law, hammond@law.ufl.edu

Ariel Jurow Kleiman

Gabriel Scheffler

Follow this and additional works at: https://scholarship.law.ufl.edu/facultypub

Part of the Law and Society Commons

Recommended Citation

Andrew Hammond, Ariel Jurow Kleiman, \& Gabriel Scheffler, How the COVID-19 Pandemic Has and

Should Reshape the American Safety Net, 105 Minn. L. Rev. Headnotes 154 (2020)

This Article is brought to you for free and open access by the Faculty Scholarship at UF Law Scholarship Repository. It has been accepted for inclusion in UF Law Faculty Publications by an authorized administrator of UF Law Scholarship Repository. For more information, please contact kaleita@law.ufl.edu. 


\title{
Essay
}

\section{How the COVID-19 Pandemic Has and Should Reshape the American Safety Net}

\author{
Andrew Hammond, ${ }^{\dagger}$ Ariel Jurow Kleiman, ${ }^{\dagger \dagger}$ and Gabriel \\ Scheffler ${ }^{\dagger \dagger \dagger}$
}

\section{INTRODUCTION}

The COVID-19 pandemic has delivered an unprecedented shock to the United States and the world. It is unclear precisely how long this crisis, which is both epidemiological and economic, will last, and it is difficult to gauge the extent and direction of the changes in American life these crises will cause. Nonetheless, it is beyond dispute that the COVID-19 pandemic is putting significant strain on both the ability of Americans to meet basic needs and our government's capacity to assist them. Federal, state, and local governments have responded in various ways to deploy existing safety net programs like Medicaid, SNAP (food stamps), tax credits, and unemployment insurance to meet the surge in need. At this stage of the crisis, it is worth a) identifying the ways in which the pandemic feeds on and exacerbates both racial and economic inequality in America, b) analyzing the government response in detail, c) considering which changes should outlast the current crisis, and d) addressing how government, in the future, should build social welfare programs that are better suited to meet the needs of all Americans in the coming years. This Essay tries to do these four things in a way that is cogent and useful to legal and lay audiences alike.

$\dagger$ Assistant Professor of Law, University of Florida Fredric G. Levin College of Law. Copyright (c) 2021 by Andrew Hammond.

t† Associate Professor of Law, University of San Diego School of Law. Copyright (C) 2021 by Ariel Jurow Kleiman.

††† Associate Professor of Law, University of Miami School of Law. Copyright (C) 2021 by Gabriel Scheffler.

The authors are grateful for feedback from Manasi Deshpande, Mirat Eyal-Cohen, Sarah Grusin, David Hasen, and participants in the COVID-19: Law, Economics, and Governance workshop at Yale Law School. 


\section{THE COVID-19 PANDEMIC'S INHERENT INEQUALITIES}

The current crisis is two-fold: epidemiological and economic. Both crises will have inordinate negative impacts on low-income households and communities of color. In this Part, we unpack the public health consequences of COVID-19 first. We then lay out the economic fallout from the pandemic.

\section{A. COVID-19 AS AN EPIDEMIOLOGICAL CRISIS}

Although we lack comprehensive data, low-income Americans appear both at greater risk of contracting COVID-19 and of suffering worse health outcomes as a result of the virus. ${ }^{1}$ Low-income people are at elevated risk of contracting COVID-19 for a number of possible reasons. To name a few, they are more likely to live in overcrowded housing, to use public transportation, and to work in jobs that require in-person interaction. ${ }^{2}$ In addition, they have higher rates of preexisting conditions like diabetes and chronic obstructive pulmonary disorder (COPD), ${ }^{3}$ which put them at increased risk of complications from COVID-19.4 They are also are more likely to be uninsured, ${ }^{5}$ and in part

1. See Wyatt Koma, Samantha Artiga, Tricia Neuman, Gary Claxton, Matthew Rae, Jennifer Kates, \& Josh Michaud, Low-Income and Communities of Color at Higher Risk of Serious Illness if Infected with Coronavirus, KAISER FAMILY Found. (May 2020), https://www.kff.org/coronavirus-covid-19/issue-brief/low-income-and -communities-of-color-at-higher-risk-of-serious-illness-if-infected-with-coronavirus/ [https://perma.cc/G7KB-L7DC]; Julia Lynch, Health Equity, Social Policy, and Promoting Recovery from COVID-19, 45 J. HEALTH POL. PoL'Y \& L. 983, 984-985 (2020); Max Fisher \& Emma Bubola, As Coronavirus Deepens Inequality, Inequality Worsens Its Spread, N.Y. Times (March 15, 2020), https://www.nytimes.com/2020/03/15/world/ europe/coronavirus-inequality.html [https://perma.cc/5BYC-L4KJ].

2. See Emily A. Benfer \& Lindsay F. Wiley, Health Justice Strategies to Combat COVID-19: Protecting Vulnerable Communities During A Pandemic, Health AfF. Blog (Mar. 19, 2020), https://www.healthaffairs.org/do/10.1377/hblog20200319 .757883/full/ [https://perma.cc/QEM8-ZFL8]; Rebekah L. Rollston \& Sandro Galea, The Coronavirus Does Discriminate: How Social Conditions are Shaping the COVID-19 Pandemic, CTR. For Primary Care, HaRvard MEdical SCH. (May 5, 2020), http://info .primarycare.hms.harvard.edu/blog/social-conditions-shape-covid [https://perma .cc/KE6L-VXDF].

3. Richard V. Reeves \& Jonathan Rothwell, Class and COVID: How the Less Affluent Face Double Risks, BROOKInGS InST. (Mar. 27, 2020), https://www.brookings.edu/blog/ up-front/2020/03/27/class-and-covid-how-the-less-affluent-face-double-risks / [https://perma.cc/SNF5-9RBN].

4. Centers for Disease Control and Prevention, People Who Are at Higher Risk for Severe Illness, https://www.cdc.gov/coronavirus/2019-ncov/need-extra -precautions/people-at-higher-risk.html [https://perma.cc/P5R8-HDPG].

5. Robin A. Cohen, Emily P. Terlizzi, \& Michael E. Martinez, Health Insurance Coverage: Early Release of Estimates from the National Health Interview Survey, 2018 1, 4 (May 2019) https://www.cdc.gov/nchs/data/nhis/earlyrelease/insur201905.pdf 
as a result, they have more limited access to health care. ${ }^{6}$

Likewise, although data on racial disparities in COVID-19's impacts have been limited,7 the existing data suggest that Black and Latinx populations in particular are both at greater risk of contracting COVID-19 and of suffering serious illness and dying from the virus. ${ }^{8}$

[https://perma.cc/8F5K-YFSH].

6. Peter J. Cunningham, Why Even Healthy Low-Income People Have Greater Health Risks Than Higher-Income People, Commonwealth Fund (Sept. 27, 2018), https://www.commonwealthfund.org/blog/2018/healthy-low-income-people -greater-health-risks [https://perma.cc/8TCW-GM8S].

7. See Brianna Ehley, CDC Head Apologizes for Lack of Racial Disparity Data on Coronavirus, Politico (Jun. 4, 2020), https://www.politico.com/news/2020/06/04/ coronavirus-robert-redfield-racial-disparity-cdc-301223 [https://perma.cc/7SNM -TRSE]; Lisa Cooper, State COVID-19 Data by Race, JoHns HopKINS UnIV. CoRonAVIRUS RESOURCE CTR., https://coronavirus.jhu.edu/data/racial-data-transparency [https:// perma.cc/7NUG-5XF2] ("[R]acial and ethnic information is currently available for only about $35 \%$ of the total deaths in the U.S."). Data limitations have been especially detrimental for Indigenous people, whose data are frequently misclassified or omitted from reports to health authorities. See Kate Conger, Robert Gebeloff, \& Richard A. Oppel Jr., Native Americans Feel Devastated by the Virus Yet Overlooked in the Data, N.Y. TIMES (Jul. 30, 2020), https://www.nytimes.com/2020/07/30/us/native-americans -coronavirus-data.html [https://perma.cc/LC9M-ZJVJ]; Lizzie Wade, COVID-19 Data on Native Americans Is 'A National Disgrace.' This Scientist is Fighting to Be Counted, SCIENCE (Sept. 24, 2020), https://www.sciencemag.org/news/2020/09/covid-19 -data-native-americans-national-disgrace-scientist-fighting-be-counted [https:// perma.cc/X48E-Q2PC].

8. See, e.g., Eboni G. Price-Haywood, Jeffrey Burton, Daniel Fort, \& Leonardo Seoane, Hospitalization and Mortality among Black Patients and White Patients with Covid-19, 382 N. ENG. J. MED. 2534 (2020) (analyzing data at a Louisiana hospital system and finding that Black patients accounted for over 75 percent of those hospitalized with COVID-19 and over 70 percent of those who died, even though they comprised only 31 percent of the overall patient population); Richard A. Oppel Jr., Robert Gebeloff, K.K. Rebecca Lai, Will Wright, \& Mitch Smith, The Fullest Look Yet at the Racial Inequity of Coronavirus, N.Y.Times (Jul. 5, 2020), https://www.nytimes.com/interactive/2020/ 07/05/us/coronavirus-latinos-african-americans-cdc-data.html [https://perma.cc/ V3M2-QVVV] ("Latino and African-American residents of the United States have been three times as likely to become infected as their white neighbors, ... [a]nd Black and Latino people have been nearly twice as likely to die from the virus as white people, the data shows."); The COVID TRACKIng PRoJeCt, The COVID Racial Data Tracker, https://covidtracking.com/race [https://perma.cc/P9JE-9CVQ] (finding that Black Americans are dying at a rate over 2 times higher than their population share); Dylan Scott, Covid-19's Devastating Toll on Black and Latino Americans, in One Chart, Vox (Apr. 17, 2020), https://www.vox.com/2020/4/17/21225610/us-coronavirus-death-rates -blacks-latinos-whites [https://perma.cc/R4B7-J7S7] ["Black and Latino Americans get infected with Covid-19 at alarmingly high rates and more are dying than we would expect based on their share of the population."). The available data also suggest that COVID-19 has disproportionately affected Indigenous communities in the United States, though data limitations have prevented understanding the full extent of these effects. See Sarah Hatcher et al., COVID-19 Among American Indian and Alaska Native Persons - 23 States, January 31 - July 3, 2020, CEnTERS For DisEASE ConTrol AND 
Again, there are a number of possible reasons for these disparities: Black and Latinx workers are overrepresented in many frontline occupations that put them at higher risk of contracting the virus, ${ }^{9}$ and they are less likely to be able to telework. ${ }^{10}$ Because of housing segregation, they are more likely to live in densely populated areas where it is harder to maintain social distancing ${ }^{11}$ and to face exposure to air pollution-which in turn has been linked to higher mortality rates from COVID-19.12 Black Americans in particular are also more likely to suffer from comorbidities like asthma, ${ }^{13}$ heart disease, ${ }^{14}$ and diabetes, ${ }^{15}$ which put them at higher risk of severe illness from COVID-19,16

Prevention (Aug. 28, 2020), https://www.cdc.gov/mmwr/volumes/69/wr/mm 6934e1.htm [https://perma.cc/C6SK-T6ZP]; Wade, supra note 7.

9. Hye Jin Rho, Hayley Brown, \& Shawn Fremstad, A Basic Demographic Profile of Workers in Frontline Industries, CTR. FOR ECON. AND POL'Y RES. (Apr. 2020), https:// cepr.net/wp-content/uploads/2020/04/2020-04-Frontline-Workers.pdf [https:// perma.cc/SKK9-VC7J].

10. Elise Gould \& Heidi Shierholz, Black and Hispanic Workers Are Much Less Likely To Be Able To Telework, ECON. PoL'Y INST. (Mar. 2020), https://www.epi.org/ blog/black-and-hispanic-workers-are-much-less-likely-to-be-able-to-work-from -home/ [https://perma.cc/JA4T-SR59].

11. CEnTERs For Disease Control and PREvention, COVID-19 in Racial and Ethnic Minority Groups, https://www.cdc.gov/coronavirus/2019-ncov/need-extra -precautions/racial-ethnic-minorities.html [https://perma.cc/3G7U-ZR5J].

12. See Xiao Wu, Rachel C. Nethery, Benjamin M. Sabath, Danielle Braun, \& Francesca Dominici, Exposure to Air Pollution and COVID-19 Mortality in the United States: A Nationwide Cross-Sectional Study, MEdRxiv (Apr. 27, 2020), https://www.medrxiv .org/content/10.1101/2020.04.05.20054502v2 [https://perma.cc/HRB9-6TAY]. See also Zinzi D. Bailey, Nancy Krieger, Madina Agénor, Jasmine Graves, Natalia Linos, \& Mary T. Bassett, Structural racism and health inequities in the USA: evidence and interventions, 389 THE LANCET 1453, 1456-57 (2017) (documenting adverse health outcomes associated with residential segregation); Ruqaiijah Yearby \& Seema Mohapatra, Law, Structural Racism and the COVID-19 Pandemic, 7 J. L. \& BIOS. 7-10 (2020) (describing how structural racism in housing has contributed to racial disparities in COVID-19 susceptibility).

13. Centers for Disease Control And Prevention, Most Recent National Asthma Data, https://www.cdc.gov/asthma/most_recent_national_asthma_data.htm [https:// perma.cc/T6FA-G5SC].

14. CEnters for Disease Control And PREvention, $A$ Closer Look at African American Men and High Blood Pressure Control 1, 8 (2010) https://www.cdc.gov/bloodpressure/docs/African_American_Executive_Summary.pdf [https://perma.cc/5X36 -TCAS].

15. Centers for Disease Control and Prevention, National Diabetes Statistics Report 2020: Estimates of Diabetes and its Burden in the United States 1, 2 (2020) https://www.cdc.gov/diabetes/pdfs/data/statistics/national-diabetes-statistics -report.pdf [https://perma.cc/MST2-7CMW].

16. Centers for Disease Control and Prevention, Coronavirus Disease 2019 (COVID-19): People Who Are at Higher Risk for Severe Illness (May 14, 2020), https:// www.cdc.gov/coronavirus/2019-ncov/need-extra-precautions/people-at-higher 
and their symptoms may be further exacerbated by the physiological stresses caused by racism and discrimination. ${ }^{17}$ Finally, Black and Latinx Americans are less likely to have health insurance, ${ }^{18}$ and more likely to suffer discriminatory treatment in medical settings, ${ }^{19}$ both of which may cause them to delay or avoid seeking treatment, further compounding health inequities. ${ }^{20}$

\section{B. COVID-19 AS AN ECONOMIC CRISIS}

The same inequalities that exacerbate COVID-19 as a disease among marginalized communities also exacerbate economic harms from the COVID-triggered recession. The relationship between our country's deep and persistent inequality and COVID-19 as an economic shock will not be fully appreciated for years to come, but we can readily identify two dimensions of inequality in the U.S. that are fueling COVID-19 as an economic crisis.

The first is the nature of work in America. The United States

-risk.html [https://perma.cc/CLA2-T7DZ].

17. See Linda Villarosa, 'A Terrible Price': The Deadly Racial Disparities of Covid-19 in America, N.Y. Times MAG. (Apr. 29, 2020), https://www.nytimes.com/2020/04/29/ magazine/racial-disparities-covid-19.html [https://perma.cc/KP7K-2484].

18. Cohen, Terlizzi \& Martinez, supra note 5, at 4.

19. See generally Dayna Bowen MatThew, Just Medicine: A Cure for RaCial INEQUALITY IN AMERICAN HEALTH CARE (2015); INSTITUTE OF MEDICINE OF THE NATIONAL ACAdemies, Unequal Treatment: Confronting RaCial AND Ethnic DisPaRities in HEAlth CARE 77 (Brian D. Smedley, Adrienne Y. Stith, \& Alan R. Nelson eds. 2003) (reviewing the literature on racial disparities in health care and finding that "[r]acial and ethnic minority patients are found to receive a lower quality and intensity of healthcare and diagnostic services across a wide range of procedures and disease areas."). See also Austin Frakt, Race and Medicine: The Harm That Comes from Mistrust, N.Y. TIMEs UPSHOT (Jan. 13, 2020), https://www.nytimes.com/2020/01/13/upshot/race-and-medicine -the-harm-that-comes-from-mistrust.html [https://perma.cc/BT6T-6F3B] ("Put simply, people of color receive less care - and often worse care - than white Americans.").

20. See, e.g., Marcella Alsan \& Marianne Wanamaker, Tuskegee and the Health of Black Men, 133 Q. J. EcoN. 407 (2018) (finding that the disclosure of the Tuskegee Study in 1972 was linked to increases in mistrust of the medical profession, decreases in physician interactions, and reduced life expectancy for Black men); Rachel Garfield, Kendal Orgera, \& Anthony Damico, The Uninsured and the ACA: A Primer - Key Facts about Health Insurance and the Uninsured amidst Changes to the Affordable Care Act, KAISER FAMILY FouND. (Jan 25, 2019), https://www.kff.org/report-section/the-uninsured-and -the-aca-a-primer-key-facts-about-health-insurance-and-the-uninsured-amidst -changes-to-the-affordable-care-act-how-does-lack-of-insurance-affect-access-to -care/ [https://perma.cc/U9Q6-PYUM] ("Uninsured people are far more likely than those with insurance to postpone health care or forgo it altogether. The consequences can be severe, particularly when preventable conditions or chronic diseases go undetected."). 
economy is very good at creating very bad jobs. One study conducted a few months before the pandemic found that 53 million American workers between ages 18 to $64-44$ percent of all workers-earn subsistence wages. ${ }^{21}$ Their median earnings were just over $\$ 10$ per hour, or about $\$ 20,000$ per year. These workers also lack job benefits like paid sick and family leave or health insurance that help individuals and households navigate economic shocks. ${ }^{22}$ This type of low-wage work in the US leaves workers at constant risk of financial calamity. The combination of low pay and no health insurance means that health costs can be financially ruinous. ${ }^{23}$ And most of these Americans are considered at-will employees so if they or their loved ones get sick, they can be fired. ${ }^{24}$

Moreover, these low-wage workers are concentrated in industries like retail, food service, janitorial, and care work-all of which have been particularly vulnerable to the shutdowns and other economic impacts of the COVID-19 crisis. Of the industries where these workers are concentrated, only administrative jobs have the potential to be done from home. ${ }^{25}$ While some of these industries could rebound in the coming months or years, it appears more likely than not that the service industry will continue to see less demand because of social

21. See Martha Ross \& Nicole Bateman, Meet The Low-Wage Workforce, BrooKINGS INST. (Nov. 7, 2019), https://brook.gs/2NIeQtN [https://perma.cc/36WG-3HNB].

22. See Kathryn Dill, Lack of Sick Time Worries Workers as Coronavirus Looms, WALL ST. J. (March 11, 2020), https://www.wsj.com/articles/lack-of-sick-time-worries-workers-as-coronavirus-looms-11583938713 [https://perma.cc/446F-RJPR].

23. See Allison K. Hoffman, The Threat of Coronavirus Medical Bankruptcy, THE HILL (Apr. 1, 2020), https://thehill.com/opinion/finance/490168-the-threat-of -coronavirus-medical-bankruptcy [https://perma.cc/G2DB-5FGD].

24. See Marshall H. Tanick, COVID-19 Highlights Need for Greater Job Protection, MinNEAPOLIS STAR-TRIB. (Apr. 19, 2020), https://www.startribune.com/covid-19 -highlights-need-for-greater-job-protection/569741532/ [https://perma.cc/6PD5 -8GPP].

25. See Neeta P. Fogg \& Paul E. Harrington, COVID-19 Shutdowns Are Hitting LowIncome Workers Especially Hard, NEW ENG. BD. OF HIGHER ED. (May 18, 2020), https:// nebhe.org/journal/covid-19-shutdowns-are-hitting-low-income-workers-especially -hard/ [https://perma.cc/JH3X-A54N] (finding that, in the New England region, eight of ten jobs lost between mid-March and mid-April were in industries characterized by below-average skill requirements and wages); Matthew Dey \& Mark A. Loewenstein, How Many Workers Are Employed In Sectors Directly Affected By COVID-19 Shutdowns, Where do They Work, and How Much do They Earn?, MonTHLY LAB. REV., U.S. BuR. OF LAB. STAT. (Apr. 2020), https://doi.org/10.21916/mlr.2020.6 [https://perma.cc/MLW8 -ML4Q]; Eric Morath \& Rachel Feintzeig, 'I Have Bills I Have to Pay.' Low-Wage Workers Face Brunt of Coronavirus Crisis, WALL ST. J. (March 20, 2020), https://www.wsj.com/ articles/i-have-bills-i-have-to-pay-low-wage-workers-face-brunt-of-coronavirus -crisis-11584719927 [https://perma.cc/WNP3-2VLQ]. 
distancing measures and the deepening economic crisis. ${ }^{26}$ And Black and Latinx workers are disproportionately disadvantaged during this economic downturn as they are concentrated in the hardest-hit sectors, are paid less, have fewer financial assets, and are less likely than white workers to be free to work remotely. ${ }^{27}$

The second is the fractured and inequitable distribution of government support. ${ }^{28}$ Although Congress initially acted quickly to provide pandemic-related assistance, it did so through existing transfer programs. As a result, those who are intentionally excluded from safety net programs during normal times, such as childless households, jobless individuals, and immigrants, have been difficult to reach. ${ }^{29}$ Moreover, rampant worker misclassification in many lowwage industries, as well as growth of the "gig economy," means that many workers will not receive support provided only to employees,

26. See Rakesh Kochhar \& Amanda Barroso, Young Workers Likely to be Hard Hit as COVID-19 Strikes a Blow to Restaurants and Other Service Sector Jobs, PEW RES. CTR. (March 27, 2020), https://www.pewresearch.org/fact-tank/2020/03/27/young -workers-likely-to-be-hard-hit-as-covid-19-strikes-a-blow-to-restaurants-and-other -service-sector-jobs/ [https://perma.cc/7GZ9-5SJA].

27. See Michael Karpman, Stephen Zuckerman, Dulce Gonzalez, \& Genevieve M. Kenney, The COVID-19 Pandemic Is Straining Families' Abilities to Afford Basic Needs, URBAN INST. (Apr. 28, 2020), https://www.urban.org/research/publication/covid-19 -pandemic-straining-families-abilities-afford-basic-needs [https://perma.cc/9R66 -2M5C]; see also Elise Gould, Daniel Perez, \& Valerie Wilson, Latinx Workers-Particularly Women-Face Devastating Job Losses in the COVID-19 Recession, ECON. POL'Y INST. (Aug. 20, 2020), https://www.epi.org/publication/latinx-workers-covid/ [https:// perma.cc/A7A2-C8PJ]; Elise Gould \& Valerie Wilson, Black Workers Face Two of the Most Lethal Preexisting Conditions for Coronavirus-Racism and Economic Inequality, ECON. POL'Y INST. (June 1, 2020), https://www.epi.org/publication/black-workers -covid/ [https://perma.cc/4TN6-CN5S]; Jeanna Smialek \& Jim Tankersley, Black Workers, Already Lagging, Face Big Economic Risks, N.Y. Times (June 1, 2020), https://www.nytimes.com/2020/06/01/business/economy/black-workers -inequality-economic-risks.html [https://perma.cc/CPH6-E4C9].

28. See David Super, The Crisis is Exposing the Harm Structural Attacks on AntiPoverty Programs Have Done, BALKINIZATION (May 23, 2020), https://balkin .blogspot.com/2020/05/the-crisis-is-exposing-harm-structural.html? $\mathrm{m}=0$ \&version= meter+at+null [https://perma.cc/N4PT-HMGX].

29. Id. (making this point); Margot L. Crandall-Hollick, COVID-19 and Direct Payments to Individuals: Summary of the 2020 Recovery Rebates/Economic Impact Payments in the CARES Act (P.L. 116-136), CONG. RES. SERV., (Apr. 17, 2020), https:// crsreports.congress.gov/product/pdf/IN/IN11282 [https://perma.cc/QD6Q-DKG3] (explaining that "many low-income individuals and families, including workers without children who do not receive benefits like the EITC or child credit, may not have filed a 2018 or 2019 income tax return" and as such "would not receive these rebates in 2020, unless they manually provided information to the IRS via their nonfiler portal ...."). 
such as paid leave. ${ }^{30}$ Lastly, some households are intentionally excluded from COVID-19-related benefits, including undocumented individuals and their U.S. citizen or legal resident family members. ${ }^{31}$ The Migration Policy Institute estimates that this exclusion resulted in the denial of cash stimulus payments to 5.5 million U.S. citizens and legal permanent residents because their tax returns included someone who lacks a social security number. ${ }^{32}$

Even those eligible for pandemic-related benefits have been thwarted by program complexity and technology problems. ${ }^{33}$ According to the Economic Policy Institute, for every ten successful recipients of pandemic-related unemployment benefits, an additional two applicants gave up because the application process was too onerous, and three to four could not finish the process due to technology problems. ${ }^{34}$ Given the direct relationship between technological and economic inequality, 35 these barriers affect the neediest applicants the most.

30. Alex Rosenblat, Gig Workers Are Here to Stay. It's Time to Give Them Benefits, HARV. BUS. REV. (July 03, 2020), https://hbr.org/2020/07/gig-workers-are-here-to -stay-its-time-to-give-them-benefits [https://perma.cc/WJ43-CGWP].

31. See Muzaffar Chishti \& Jessica Bolter, Vulnerable to COVID-19 and in Frontline Jobs, Immigrants Are Mostly Shut Out of U.S. Relief, MigRATION PoL'y InST. (Apr. 24, 2020), https://www.migrationpolicy.org/print/16745\#.XuFpA55KgUs [https:// perma.cc/N2TY-74HR].

32. $I d$.

33. See Renu Zaretsky, CARES Act Support is Falling Short, TAxVox (May 6, 2020), https://www.taxpolicycenter.org/taxvox/cares-act-support-falling-short\#: :text= The $\% 20$ CARES $\% 20$ Act $\% 20$ expanded $\% 20$ eligibility,unemployment $\% 20$ benefits $\% 20$ by\%2013\%20weeks [https://perma.cc/XY3A-2VMP] (detailing problems with complexity and technological failures plaguing CARES Act benefits); Scott Roybal \& Jennifer N. Le, The CARES Act - Who's Minding the Store, SHEPPARD MULLIN Gov'T CONTRACTS \& INVESTIGATIONS BLOG (Apr. 9, 2020), https://www.governmentcontractslawblog .com/2020/04/articles/government-contracts-law/cares-act-minding-the-store/ [https://perma.cc/G9RU-ZRF9] (detailing myriad oversight and reporting pitfalls that make compliance with CARES Act rules difficult for business owners).

34. Ben Zipperer \& Elise Gould, Unemployment Filing Failures: New Survey Confirms that Millions of Jobless Were Unable to File an Unemployment Insurance Claim, ECON. POL'y INST. (Apr. 28, 2020), https://www.epi.org/blog/unemployment-filing -failures-new-survey-confirms-that-millions-of-jobless-were-unable-to-file-an -unemployment-insurance-claim/ [https://perma.cc/89HW-2FG3]; see also Heather Long, Jeff Stein, Lisa Rein, \& Tony Romm, Stimulus Checks and Other Coronavirus Relief Hindered by Date Technology and Rocky Government Rollout, WASH. PosT (Apr. 17, 2020), https://www.washingtonpost.com/business/2020/04/17/stimulus -unemployment-checks-delays-government-delays/ [https://perma.cc/FL7D-T476].

35. Gaby Galvin, States Struggle to Bridge Digital Divide, U.S. NEws (Mar. 16, 2017), https://www.usnews.com/news/best-states/articles/2017-03-16/internet-access -a-staple-of-american-life-yet-millions-remain-under-connected [https://perma.cc/ HC8Y-QCPJ]. 
Importantly, and as we discuss at the end of the Essay, systemic racism built into the design of government programs means that gaps in benefit distribution will track existing racial fault lines. As one example, longstanding and well-documented racial inequities in access to lending means that businesses owned by Black and Latinx entrepreneurs have been far less likely to receive pandemic-related small business support. ${ }^{36}$ Congress's inability or refusal to pass an additional stimulus in the fall of 2020 has worked to similar effect, both ignoring and exacerbating the racially disparate impact of the pandemic. While the overall unemployment rate in the third quarter of 2020 dropped to single digits-from a high of nearly 15 percent in May ${ }^{37}$ - the unemployment rate among Black and Latinx workers remained in the double digits, at 13.2 percent and 11.2 percent respectively. ${ }^{38}$ In October 2020, researchers estimated that the number of poor people had grown by 8 million since May 2020, with especially severe increases for Black and Latinx individuals. 39 The lack of urgency among policymakers to support struggling workers and families, many of whom are nonwhite, thus reflects a blindness to the particular harm that these crises have wrought on Black and Latinx people.

The twin crises of the pandemic and recession will affect everyone worldwide, but none as catastrophically as the poor. The inadequacy of our band-aid responses to these longstanding social fissures are now laid bare. However, more than merely holding a magnifying

36. Claire Kramer Mills \& Jessica Battisto, Double Jeopardy: Covid-19's Concentrated Health and Wealth Effects in Black Communities, FEDERAL RESERVE BANK OF NEW YoRK, 4-6 (2020), https://www.newyorkfed.org/medialibrary/media/ smallbusiness/DoubleJeopardy_COVID19andBlackOwnedBusinesses [https://perma .cc/37DJ-4MB7].

37. U.S. Bur. Labor Stat., Labor Force Statistics from the Current Population Survey, https://data.bls.gov/cgi-bin/surveymost?bls [https://perma.cc/3LN7-WV7M] (select "Unemployment Rate (Seasonally Adjusted) - LNS14000000," choose "retrieve data," then select time range 2010 to 2020).

38. U.S. Bur. Labor Stat., E-16. Unemployment Rates by Age, Sex, Race, and Hispanic or Latino Ethnicity (Oct. 5 2020), https://www.bls.gov/web/empsit/cpsee_e16.htm [https://perma.cc/MT6E-HQRE].

39. See Jason DeParle, 8 Million Have Slipped into Poverty Since May as Federal Aid Has Dried Up, N.Y. Times (Oct. 15, 2020), https://www.nytimes.com/2020/10/15/ us/politics/federal-aid-poverty-levels.html [https://perma.cc/YY2Q-5VCK] (citing Zachary Parolin, Megan Curran, Jordan Matsudaira, Jane Waldfogel, \& Christopher Wimer, Monthly Poverty Rates in the United States During the COVID-19 Pandemic, (Poverty and Social Policy Working Paper Oct. 15, 2020), https://static1.squarespace .com/static/5743308460b5e922a25a6dc7/t/5f87c59e4cd0011fabd38973/1602733 471158/COVID-Projecting-Poverty-Monthly-CPSP-2020.pdf [https://perma.cc/YS3] $-\mathrm{XX} 2 \mathrm{Z}])$. 
glass to our collective failures, these crises present an opportunity for meaningful change. The next Part describes policymakers' early reforms to safety net programs, which aimed to address these crises among struggling U.S. households.

\section{THE INITIAL RESPONSE: THE U.S. SAFETY NET AS A SHORT- TERM FIX}

To date, Congress passed and President Trump signed four major pieces of legislation to address the COVID-19 crisis. The first, the Coronavirus Preparedness and Response Supplemental Appropriations Act, enacted on March 6, 2020, provided $\$ 8.3$ billion in funding for federal agencies to respond to the outbreak of the virus in the U.S. and abroad. ${ }^{40}$ The second, the Families First Coronavirus Response (Families First) Act, signed into law on March 18, 2020, focused on both the epidemiological and economic crises discussed in Part I. ${ }^{41}$ This legislation included additional funding for food assistance. ${ }^{42}$ Nine days later, on March 27, the President signed the Coronavirus Aid, Relief, and Economic Security (CARES) Act, a $\$ 2$ trillion stimulus bill aimed at COVID-19 and the attendant economic crisis. ${ }^{43}$ Then on April 24, the President signed the Paycheck Protection Program and Health Care Enhancement Act into law, which provided additional funding for programs under the CARES Act. ${ }^{44}$ These laws contain numerous provisions that alter safety net programs, such as cash assistance, including through the Internal Revenue Service (IRS); near-cash assistance, including SNAP (food stamps); medical assistance, including Medicaid; and job-related assistance, including state unemployment insurance (UI) and federal workforce incentive programs. ${ }^{45}$ In this Part, we

40. The Coronavirus Preparedness and Response Supplemental Appropriations Act, Pub. L. 116-123.

41. The Families First Coronavirus Response Act, Pub. L. 116-127.

42. Id.; see also Kellie Moss, The Families First Coronavirus Response Act: Summary of Key Provisions, KAISER FAMILY Found. (March 23, 2020), https://www.kff.org/ coronavirus-covid-19/issue-brief/the-families-first-coronavirus-response-act -summary-of-key-provisions/ [https://perma.cc/4FKQ-VLDG].

43. The Coronavirus Aid, Relief, and Economic Security Act, Pub. L. 116-138 [hereinafter CARES Act].

44. Paycheck Protection Program and Health Care Enhancement Act, Pub. L. 116139.

45. The Families First Coronavirus Response Act, Pub. L. 116-127; CARES Act, Pub. L. 116-138; see also Marianne Bitler, Hilary W. Hoynes, \& Diane Whitmore Schanzenbach, The Social Safety Net in the Wake of COVID-19 (NBER Working Paper No. 27796) (discussing the government response and suggesting that the timing, magnitude, and coverage of the policy responses explain, in part, why there is still so much 
relate each change in turn and briefly address how some of these efforts have fallen short, particularly for the most vulnerable groups.

\section{A. Cash and near-Cash Assistance}

The United States distributes direct assistance through various programs including refundable tax credits, food assistance, and through social insurance policies like the Social Security old-age and disability programs. Congress used the existing infrastructure of the IRS's tax credits and SNAP (food stamps) to deliver additional assistance during the pandemic.

\section{IRS}

As is often true during national crises, the IRS bears much of the responsibility for shoring up the economy during the current crisis. In this case, pursuant to the CARES Act, the agency has been responsible for sending "recovery rebate" checks to millions of American households. ${ }^{46}$ The CARES Act provides $\$ 1,200$ to each adult and $\$ 500$ to each child, which begins to phase out for income above $\$ 75,000$ for individuals ( $\$ 150,000$ for married couples). ${ }^{47}$

Although this individual payment may seem relatively generous, it is worth noting that another tax benefit in the CARES Act is estimated to provide an average benefit of $\$ 1.6$ million each to certain taxpayers with income over $\$ 1$ million. ${ }^{48}$ The provision allows wealthy taxpayers to deduct unlimited losses arising from pass-through businesses, enabling them to reduce or even eliminate their other taxable income. ${ }^{49}$ While the provision may seem to be a worthwhile effort to protect taxpayers who suffer business losses as a result of COVID-19, taxpayers can also retroactively claim losses incurred in 2018 and 2019, before the start of the COVID-19 pandemic and recession. ${ }^{50}$ In total, this tax benefit is projected to cost over $\$ 70$ billion in lost tax

need despite the robust policy response).

46. I.R.C. $§ 6428$ (West 2020) (providing for a refundable tax credit of $\$ 1,200$ per individual and $\$ 500$ per child, to phase out beginning at $\$ 150,000$ gross income for joint returns, $\$ 75,000$ for individuals); CARES Act, H.R. 748, 116th Congress $\S 2201$ (2020) (enacted).

47. I.R.C. $§ 6428(c)$ (West 2020).

48. See Clint Wallace, The Troubling Case of the Unlimited Pass-Through Deduction: Section 2304 of the CARES Act, U. CHI. L. REv. ONLINE (2020), https://lawreviewblog.uchicago.edu/2020/06/29/cares-2304-wallace/ [https://perma.cc/Y78T -KSL3].

49. CARES Act, § 2304; Wallace, supra note 48.

50. Id.; I.R.C. § 6511(a) (allowing taxpayers to file a refund claim for up to three years prior). 
revenue in 2020.51

Although nominally structured as a tax credit, the recovery rebate is fully refundable, which means that even those without taxable income can receive the stimulus payment. ${ }^{52}$ In order to authorize the IRS to send the credit to taxpayers in advance of their 2020 tax returns (which will not be filed until 2021), the advance credit amount is calculated based on taxpayers' 2019 income. ${ }^{53}$ However, for low-income taxpayers with income well below the phase-out thresholds, the year used will not matter. That is, all low-income individuals are eligible for the full credit amount, provided that they and their family members have work-eligible social security numbers. Importantly, even those who owe back taxes should receive the full amount, as the rebate credit cannot be diverted to satisfy outstanding tax liabilities or other federal or state debts, aside from child support offsets. ${ }^{54}$

Distribution problems plagued the rollout of these payments. Six months after passage of the CARES Act, approximately 9 million people still had not received their stimulus payments because the IRS lacked their contact information. ${ }^{55}$ This group is largely composed of people who do not normally file a tax return because their income is below the filing threshold, a group that includes low-income families with children, the long-term unemployed, and childless adults. ${ }^{56}$ Many who received the payments on preloaded debit cards discarded the unmarked envelopes the cards arrived in because they had not received prior notice to expect the payment. ${ }^{57}$ Meanwhile, billions of dollars of stimulus payments were erroneously sent to ineligible

51. Joint Comm. on taxation, JCX-11-20, Estimated Revenue Effects Of The Revenue Provisions Contained In An Amendment In The NAture OF A Substitute To H.R. 748, The “Coronavirus Aid, Relief, And Economic SECURity ('CARES') ACT,” As PASSEd By The Senate ON MARCh 25, 2020, ANd SCheduled For Consideration By The HOUSE OF REPRESENTATIVES ON MARCH 27, 2020 (Mar. 26, 2020), https://www.jct .gov/publications.html?func=startdown\&id=5252 [https://perma.cc/Y32G-CQ5S].

52. I.R.C. § 6428(f) (West 2020).

53. Id.

54. CARES Act, $\S 2201(d)$.

55. Michelle Singletary, IRS Is Trying to Reach 9 Million People Who Haven't Collected Their Stimulus Payments, WASH. Post (Sept. 11, 2020), washingtonpost.com/ business/2020/09/11/irs-stimulus-check-letter/ [https://perma.cc/D7SJ-H8KS].

56. Id.; ChuCK MARR, KRIS CoX, KathleEN BRyANT, STACy DEAN, ROXY CAINES, \& ARloC Sherman, Ctr on Budget \& Pol'y Priorities, Aggressive State Outreach Can HelP Reach the 12 Million Non-Filers Eligible for Stimulus Payments 1 (Oct. 14, 2020), https://www.cbpp.org/sites/default/files/atoms/files/6-11-20tax.pdf [https:// perma.cc/RZ9L-UM7N].

57. Singletary, supra note 55 . 
foreign workers as well as deceased individuals. 58

In addition to the various stimulus bills passed by Congress, the Trump Administration took unilateral action in an attempt to inject cash into the economy. On August 8, 2020, the White House issued a memorandum directing the Treasury to allow deferred withholding and payment of payroll taxes for workers earning less than $\$ 4,000$ per bi-weekly pay period. ${ }^{59}$ The deferral period runs from September 1 through December 31, 2020. However, the taxes were only deferred, not forgiven, meaning that employers and workers who take advantage of the policy would owe all unpaid taxes at the end of the year. ${ }^{60}$ Employers could also face liability for taxes they fail to withhold, making the deferral particularly unattractive for them. ${ }^{61}$ Further, even if Congress ultimately voted to forgive the unpaid taxesthe odds of which seem slim in the current climate-the relief would only benefit employed workers, ignoring unemployed individuals.

\section{Food Assistance}

Since the COVID-19 pandemic struck the U.S., rates of household food insecurity have doubled and rates of childhood food insecurity have tripled. ${ }^{62}$ In the Families First Act, Congress authorized the Department of Agriculture to allow states to create a "Pandemic EBT" program. ${ }^{63}$ Pandemic EBT is an electronic food assistance benefit for

58. Sacha Pfeiffer, Foreign Workers Living Overseas Mistakenly Received \$1, 200 U.S. Stimulus Checks, NPR (Aug. 5, 2020), https://www.npr.org/2020/08/05/ 898903600/foreign-workers-living-overseas-mistakenly-received-1-200-u-s -stimulus-checks [https://perma.cc/Q2UZ-QRPN]; Lorie Konish, About \$1.4 Billion in Stimulus Checks Sent to Deceased Americans, CNBC (Jun. 25, 2020), https://www.cnbc .com/2020/06/25/1point4-billion-in-stimulus-checks-sent-to-deceased-individuals .html [https://perma.cc/ULB2-NG8P].

59. Memorandum from the White House to the Sec'y of the Treasury (Aug. 8, 2020), https://www.whitehouse.gov/presidential-actions/memorandum-deferring -payroll-tax-obligations-light-ongoing-covid-19-disaster/ [https://perma.cc/A57G -M5WT].

60. Andy Grewal, The Payroll Tax Relief Program Won't Work, YALE J. REG.: NoticE \& CoMment (Aug. 12, 2020), https://www.yalejreg.com/nc/the-payroll-tax-relief -program-wont-work/ [https://perma.cc/Q95H-T8P5].

61. Id.

62. Diane Schanzenbach \& Abigail Pitts, How Much Has Food Insecurity Risen? Evidence from the Census Household Pulse Survey, Nw. UNIV. INST. FOR POL'Y RES. (June 10, 2020), https://www.ipr.northwestern.edu/documents/reports/ipr-rapid-research -reports-pulse-hh-data-10-june-2020.pdf [https://perma.cc/4R5S-XAB5]; Lauren Bauer, The COVID-19 Crisis Has Already Left Too Many Children Hungry in America, Brookings InSt. The Hamilton ProJ. (May 6, 2020).

63. The Families First Coronavirus Response Act $\S 1101(\mathrm{~b})$-(i). By late August, the United States Department of Agriculture had approved Pandemic EBT programs in 
children who would miss out on free or reduced-price meals at school. ${ }^{64}$ The Families First Act also made emergency appropriations to the WIC nutritional program for pregnant women and young children and to TEFAP, one of the commodity food programs. ${ }^{65}$ In addition to allowing states to make "emergency allotments" for SNAP households, Congress also included in the Families First Act an additional $\$ 100$ million in nutrition assistance for the three territories that federal law excludes from SNAP: the Commonwealth of the Northern Mariana Islands (CNMI), Puerto Rico, and American Samoa. ${ }^{66}$

The CARES Act not only expanded federal funding of SNAP assistance by over $\$ 16$ billion, ${ }^{67}$ it also blocked ongoing efforts by the Trump Administration to restrict access to food assistance. 68 The key

all fifty states, D.C., and the U.S. Virgin Islands. See Press Release, U.S. Dep't of Agric., USDA Approves Program to Feed Kids in Idaho: Pandemic EBT now available in all 50 states (Aug. 19, 2020), https://www.fns.usda.gov/news-item/usda-032920 [https:// perma.cc/LCD3-4FP6]. There are reports of a failure to deliver these benefits to families because of administrative errors at the state level. See, e.g., Natalie Allison, Tennessee Could Forfeit \$60M in Federal Food Aid for Low-Income Families During Coronavirus Pandemic, NASHVIlLE TENNESSEAN (July 30, 2020), https://www.tennessean.com/ story/news/politics/2020/07/30/tennessee-may-forfeit-60-m-pandemic-ebt-funds -applications-stall/5535427002/ [https://perma.cc/B48E-KMEW].

64. State Guidance on Coronavirus Pandemic EBT (P-EBT), Food \& NuTRIT. SERV. (June 2, 2020), https://fns-prod.azureedge.net/sites/default/files/resource-files/ SNAP-CN-COVID-PEBTGuidance.pdf [https://perma.cc/AM5Y-DUUX] (explaining that the "household allotment amount will be no less than the value of school meals at the free rate over the course of five (5) school days for each eligible child in the household.").

65. Families First Act, Title I (authorizing $\$ 500$ million for WIC and $\$ 400$ million for TEFAP through September 30, 2021).

66. Families First Act, $\S \S 1102,2302(a)(1)$. These three territories normally receive a block grant of funding as opposed to the entitlement funding enjoyed by the rest of the United States. See Andrew Hammond, Territorial Exceptionalism and the American Welfare State, 119 MICH. L. REV. (forthcoming 2021) (discussing the exclusion of these territories from safety net programs including SNAP).

67. House Comm. on Appropriations, Rpt. 116-446 at 73 (116th Cong. 2020), https://www.congress.gov/116/crpt/hrpt446/CRPT-116hrpt446.pdf [https:// perma.cc/U2EL-2HGY].

68. In addition to the Able-Bodied Adults Without Dependent time limit discussed below, the Trump Administration has proposed, but not finalized two other rules that would reduce or eliminate benefits for millions of SNAP recipients. The Trump Administration has proposed revising "broad-based categorical eligibility" (BBCE), which allows states to make low-income families automatically eligible for SNAP benefits if they have already qualified to receive certain other types of public assistance. See Revision of Category Eligibility in the Supplemental Nutritional Assistance Program, 84 Fed. Reg. 142,35570 (July 24, 2019) (to be codified at 7 C.F.R. § 273). The Trump Administration's proposed rule would remove more than 3 million Americans from SNAP. See Dottie Rosenbaum, SNAP's "Broad-Based Categorical Eligibility" Supports Working Families and Those Saving for the Future, CTR. ON BUdGET \& POL'Y PRIORITIES 
legislative pause on the Administration's efforts involves a time limit for over a million SNAP recipients. ${ }^{69}$ Since the Welfare Reform Act of 1996, SNAP includes a time limit for those recipients who are considered Able-Bodied Adults Without Dependents (ABAWDs) within the meaning of the Food Stamp Act. ${ }^{70}$ ABAWDs currently can only receive three months of SNAP benefits in a three-year period unless they meet a work requirement or are exempted from that work requirement. ${ }^{71}$ States, however, can apply to the federal government for a waiver if the state's unemployment rate is above the national unemployment rate. $^{72}$ The U.S. Department of Agriculture promulgated a rule that would limit the extent to which states can waive a statutory provision that places a time limit on ABAWDs' receipt of SNAP benefits. ${ }^{73}$ The Department of Agriculture estimated that over one million SNAP recipients would be impacted, and one estimate suggests over 750,000 Americans would lose their SNAP benefits under the proposed rule. ${ }^{74}$

(July 30, 2010), https://www.cbpp.org/research/food-assistance/snaps-broad-based -categorical-eligibility-supports-working-families-and [https://perma.cc/5V8H

-R2JU]. The other proposed rule would impact how states account for the costs of utilities, including home heating and cooling, in determining SNAP benefits. See Supp. Nutri. Assistance Prog.: Standardization of State Heating and Cooling Standard Utility Allowances, 84 Fed. Reg. 192,52809 (Oct. 3, 2019). The change will result in 19 percent of SNAP households receiving lower SNAP monthly benefits. Id. at App'x: Regulatory Impact Analysis Supplement to Standardization of State Heating and Cooling Standard Utility Allowances 29.

69. The Families First Coronavirus Response Act, $\S 2301(a)$.

70. ABAWDs are defined as recipients ages eighteen to forty-nine who do not have a disability or are not caring for children or other dependents in their own home. 7 C.F.R. $§ 273.24$ (c).

71. 7 U.S.C. $\S 2015($ o); 7 C.F.R. § 273.24(b) (2019) See also Andrew Hammond, Litigating Welfare Rights: Medicaid, SNAP, and the Legacy of the New Property, $115 \mathrm{Nw}$. U. L. REv. 361 (2020) (discussing the failed efforts to include such a policy in the 2018 Farm Bill and the subsequent regulatory strategy).

72. 7 U.S.C. $\S 2015(0)(4)(A)$ (allowing states to seek a waiver to suspend the ABAWD time limit for "any group of individuals in the State" if the requested waiver area "has an unemployment rate of over 10 percent" or "does not have a sufficient number of jobs to provide employment for the individuals.").

73. Food \& Nutrit. Serv., U.S. Dep't of Agric., Final Rule for Supp. Nutri. Assistance Prog.: Requirements for Able-Bodied Adults Without Dependents, 84 Fed. Reg. 66782, 66802 (Dec. 5, 2019).

74. See Danielle Paquette \& Jeff Stein, Trump Administration Aims to Toughen Work Requirements for Food Stamp Recipients, WASH. PosT (Dec. 20, 2018), https:// www.washingtonpost.com/business/economy/trump-administration-aims-to -toughen-work-requirements-for-food-stamps-recipients/2018/12/20/cf687136 -03e6-11e9-b6a9-0aa5c2fcc9e4_story.html [https://perma.cc/FC53-GDHZ]; Lauren Bauer, Workers Could Lose SNAP Benefits Under Trump's Proposed Rule, BRooKINGS INSTIT. (Dec. 20, 2018), https://www.brookings.edu/blog/up-front/2018/12/20/ workers-could-lose-snap-benefits-under-trumps-proposed-rule/ [https://perma.cc/ 
However, before the rule could go into effect as planned last April, a federal court preliminarily enjoined the Department of Agriculture from implementing it nationwide. In the Families First Act, Congress blocked all SNAP work requirements beginning in April 2020 continuing until a month after the COVID-19 public health emergency declaration is lifted..$^{75}$ Meanwhile, the Trump Administration filed its notice of appeal for the federal district court's injunction to the D.C. Circuit. ${ }^{76}$

\section{B. Medical Assistance}

Policymakers and private actors have taken several steps to address the costs to patients for COVID-19 testing, whereas measures to cover the costs to patients of COVID-19 medical care have been more piecemeal. Policymakers have also provided financial support for health care providers and states struggling with the cost of medical care, though the distribution of support has been widely criticized as poorly targeted and inequitable. ${ }^{77}$

\section{Patients}

The Families First Act requires most private health plans, Medicare, and Medicaid to cover FDA-approved testing for COVID-19, as well as most out-of-pocket costs associated with the tests, for as long as there is a declared public health emergency. ${ }^{78}$ The law also authorizes full federal funding for states that use their Medicaid program to cover the cost of testing for uninsured people during this period, and authorizes $\$ 1$ billion for the National Disaster Medical System to pay for COVID-19 testing for the uninsured population. ${ }^{79}$ The subsequently-passed CARES Act expands the testing coverage provisions beyond FDA-approved testing, includes a narrow measure to try to insulate patients from surprise bills for COVID-19 testing ${ }^{80}$ and provides

EW8D-E3P5] [drawing on research to conclude that "strict enforcement of work requirements will sanction not only those who are able to work but are choosing not to, but those who are unable to work and those who are unable to find work or prove that they have met the requirement.").

75. Families First Coronavirus Response Act, § 2301(a).

76. D.C. et. al. v. U.S. Dep't of Agric., 20-cv-119 (notice of appeal to D.C. Cir. filed by Sec'y Perdue, U.S. Dep't of Agric.) (D.D.C. May 12, 2020).

77. See infra notes $97-98$ and accompanying text.

78. Families First Coronavirus Response Act, $\S \S 6001-6004$.

79. Families First Coronavirus Response Act, $\S 6004$, Title V.

80. CARES Act, $\S 3202$. But see Katie Keith, COVID-19 Package \#3: The Coverage Provisions, HEALTh AfF. Blog (March 21, 2020), https://www.healthaffairs.org/do/ 10.1377/hblog20200320.739699/full/ [https://perma.cc/25P9-VRX9] (discussing the limitations of this provision). 
that a COVID-19 vaccine (once developed) would be covered without cost-sharing. ${ }^{81}$ However, these testing coverage provisions are not comprehensive: they do not guarantee access to free COVID-19 testing for the uninsured, and they have limitations which in practice mean that some people with insurance coverage are still on the hook for testing-related out-of-pocket costs. ${ }^{82}$

The actions to cover the cost of medical care associated with COVID-19 have been much more limited. A number of private insurance companies have also pledged to voluntarily waive cost-sharing for COVID-19 medical care. ${ }^{83}$ However, their specific policies vary, and there are loopholes and exceptions that substantially limit the circumstances in which these pledges apply. ${ }^{84}$ Some states also expanded health insurance coverage through reopening enrollment on the Affordable Care Act (ACA) insurance exchanges. ${ }^{85}$ Twelve states and DC run their own exchanges through separate state websites, whereas the other 38 states rely on the federal exchange platform. All but one

81. CARES Act, $\S \S 3203,3713$.

82. See Nisha Kurani, Karen Pollitz, Dustin Cotliar, Nicolas Scanosky, \& Cynthia Cox, COVID-19 Test Prices and Payment Policy, Peterson-KFF Health System Tracker (Jul. 15, 2020), https://www.healthsystemtracker.org/brief/covid-19-test-prices-and -payment-policy/ [https://perma.cc/5PEF-UK5P]. See also Sarah Kliff, Coronavirus Tests Are Supposed to Be Free. The Surprise Bills Come Anyway., N.Y. TimEs UPSHOT (Sept. 9, 2020), https://www.nytimes.com/2020/09/09/upshot/coronavirus-surprise-test -fees.html [https://perma.cc/8LFY-X6LF ] ("About 2.4 percent of coronavirus tests billed to insurers leave the patient responsible for some portion of payment, according to the health data firm Castlight. With 77 million tests performed so far, it could add up to hundreds of thousands of Americans who receive unexpected bills.").

83. America's HeAlth InSURAnCe Plans (AHIP), Health Insurance Providers Respond to Coronavirus (COVID-19) (May 29, 2020), https://www.ahip.org/health -insurance-providers-respond-to-coronavirus-covid-19/] [https://perma.cc/2DBU $-8 \mathrm{Y} 9 \mathrm{G}]$.

84. See, e.g., Reed Abelson, Now That Coronavirus Tests are Free, Some Insurers Are Waiving Costs for Treatment, N.Y. TimEs (March 31, 2020), https://www.nytimes.com/ 2020/03/19/health/coronavirus-tests-bills.html [https://perma.cc/Q9ZA-83LV]

(" $[\mathrm{A}]$ lot of fine print remains: Some of the insurers have waived cost sharing for the next two months, while others are eliminating out-of-pocket expenses only for hospital stays. Many require people to go to hospitals and doctors within their plans. Another big caveat: The companies' decisions also do not apply to the health plans they administer for employers that self-insure. Each of those companies will have to decide whether they will follow the insurers' lead.").

85. See State COVID-19 Health Policy Actions, Tbl. On Marketplace Special Enrollment Period (SEP), KAISER FAMILY FOUND., https://www.kff.org/other/state -indicator/state-covid-19-health-policy-actions/?currentTimeframe=0\&selectedDistributions=marketplace-special-enrollment-period-sep\&sortModel $=\% 7 \mathrm{~B} \% 22$ colId\%22:\%22Location\%22,\%22sort\%22:\%22asc\%22\%7D [https://perma.cc/PCJ3 -Y223]. 
of the states that run their own exchanges reopened enrollment in the spring, making it easier for people in those states to sign up for health insurance during the current pandemic. ${ }^{86}$ Several of these state exchanges reported thousands of newly enrolled individuals soon after they reopened enrollment. ${ }^{87}$

However, the Trump Administration declined to reopen enrollment in the other 38 states, despite pressure from Congress and the health care industry for them to do so. ${ }^{88}$ According to one estimate, doing so for 60 days would have served to enroll 440,000 to 640,000 Americans. ${ }^{89}$ In addition, as of January 2020,14 states had not yet expanded their Medicaid programs under the ACA (which provides that the federal government will cover most of the cost of expanding Medicaid coverage to low-income adults), leaving over 2 million Americans without access to health insurance before the pandemic. ${ }^{90}$ This number has likely risen significantly, as early estimates suggest that millions of Americans have lost-or will lose-access to insurance due to job losses caused by the pandemic. ${ }^{91}$

86. Margot Sanger-Katz \& Reed Abelson, Eleven States Now Letting Uninsured Sign Up for Obamacare, N.Y. TIMES UPSHOT (Mar. 23, 2020), https://www.nytimes.com/ 2020/03/23/upshot/coronavirus-obamacare-marketplaces-reopen.html [https:// perma.cc/Y3G9-ZHSF].

87. Rachel Schwab, Justin Giovannelli, \& Kevin Lucia, During the COVID-19 Crisis, State Health Insurance Marketplaces Are Working to Enroll the Uninsured, COMmONWEALTH FUND (May 19, 2020), https://www.commonwealthfund.org/blog/ 2020/during-covid-19-crisis-state-health-insurance-marketplaces-are-working -enroll-uninsured [https://perma.cc/DS6B-8MAJ].

88. Margot Sanger-Katz \& Reed Abelson, Obamacare Markets Will Not Reopen, Trump Decides, N.Y. TIMES UPSHOT (Apr. 1, 2020), https://www.nytimes.com/2020/ 04/01/upshot/obamacare-markets-coronavirus-trump.html [https://perma.cc/ 7NL6-T824].

89. Emily Gee, Charles Gaba, \& Nicole Rapfogel, The ACA Marketplaces Are Poised To Weather COVID-19, CTR. FOR AM. PROGRESS (Aug. 21, 2020), https://www .americanprogress.org/issues/healthcare/reports/2020/08/21/489710/aca -marketplaces-poised-weather-covid-19/ [https://perma.cc/7T2C-4UKU].

90. Rachel Garfield, Kendal Orgera, \& Anthony Damico, The Coverage Gap: Uninsured Poor Adults in States that Do Not Expand Medicaid, KAISER FAMILY Found. (Jan. 14, 2020), https://www.kff.org/medicaid/issue-brief/the-coverage-gap-uninsured-poor -adults-in-states-that-do-not-expand-medicaid/ [https://perma.cc/FQQ8-RA27].

91. Jessica Banthin, Michael Simpson, Matthew Buettgens, Linda J. Blumberg, \& Robin Wang, Changes in Health Insurance Coverage Due to the COVID-19 Recession: Preliminary Estimates Using Microsimulation, URBAN INST. (2020), https://www.urban .org/sites/default/files/publication/102552/changes-in-health-insurance-coverage -due-to-the-covid-19-recession_4.pdf [https://perma.cc/E54R-SF8A] (estimating that the number of uninsured will rise by 2.9 million people in 2020); Stan Dorn, The COVID-19 Pandemic and Resulting Economic Crash Have Caused the Greatest Health Insurance Losses in American History, FAMILIES USA (Jul. 17, 2020), 
Finally, federal and state policymakers have also waived various regulatory requirements to promote access to telehealth during the pandemic. ${ }^{92}$ HHS has waived various restrictions on Medicare coverage of telehealth services (including allowing beneficiaries to access telehealth from their home and allowing providers to evaluate patients who only have telephones), almost all states have expanded Medicaid coverage of telehealth services, and some states have also required so-called "payment parity" for telehealth (meaning that telemedicine services must be reimbursed at the same rate as equivalent in-person services). ${ }^{93}$ States have temporarily waived licensing restrictions and provider screening requirements to allow out-of-state providers with equivalent licensing. ${ }^{94} \mathrm{~A}$ number of private insurance companies have also voluntarily expanded their coverage of telehealth services. ${ }^{95}$

\section{Providers}

The CARES Act-together with a subsequent measure, the Paycheck Protection Program and Health Care Enhancement Actprovided a total of $\$ 175$ billion in funding for hospitals and other health care entities, which have suffered steep revenue losses due to the cancellation of elective procedures. ${ }^{96}$ However, because of the

https://www.familiesusa

.org/resources/the-covid-19-pandemic-and-resulting-economic-crash-have-caused -the-greatest-health-insurance-losses-in-american-history/ [https://perma.cc/2DS3 -G9Z8] [estimating that 5.4 million workers became uninsured because of job losses they experienced between February and May 2020); Rachel Garfield, Gary Claxton, Anthony Damico, \& Larry Levitt, Eligibility for ACA Health Coverage Following Job Loss, KAISER FAMILY FOUND. (May 13, 2020), https://www.kff.org/coronavirus-covid-19/ issue-brief/eligibility-for-aca-health-coverage-following-job-loss/ [https://perma.cc/ HX9N-V8C4] (estimating that "as of May 2nd, 2020, nearly 27 million people could potentially lose ESI [employer-sponsored insurance] and become uninsured following job loss....").

92. See Gabriela Weigel, Amrutha Ramaswamy, Laurie Sobel, Alina Salganicoff, Juliette Cubanski, \& Meredith Freed, Opportunities and Barriers for Telemedicine in the U.S. During the COVID-19 Emergency and Beyond, KAISER FAMILY Found. (May 11, 2020), https://www.kff.org/womens-health-policy/issue-brief/opportunities-and-barriers -for-telemedicine-in-the-u-s-during-the-covid-19-emergency-and-beyond/ [https:// perma.cc/5DSS-4U2Q].

93. Id.

94. Id. See also Medicaid Emergency Authority Tracker: Approved State Actions to Address COVID-19, KAISER FAMILY Found. (May 29, 2020), https://www.kff.org/ coronavirus-covid-19/issue-brief/medicaid-emergency-authority-tracker-approved -state-actions-to-address-covid-19/\#Table1 [https://perma.cc/6HMW-9M7A].

95. See Weigel et al., supra note 92.

96. Bob Herman, Health Care Bailout Fund Reaches $\$ 175$ Billion, Axios (Apr. 22, 
methodology HHS used to allocate the funding, a disproportionate share of it has gone to larger, wealthier institutions, rather than those hospitals with the greatest financial need or the largest COVID-19 burden. ${ }^{97}$ In addition, HHS has distributed less funding to communities with relatively higher Black populations than is warranted based on the health or financial impacts of COVID-19, further exacerbating the unequal effects that the pandemic has had on communities of color. ${ }^{98}$

\section{States}

To help defray the costs of rising Medicaid enrollment and prevent states from cutting benefits, the Families First Act temporarily increases the Federal Medical Assistance Percentage (FMAP) for state and territorial Medicaid programs by 6.2 percentage points until the end of the public health emergency ${ }^{99}$ The Medicaid program is jointly financed by the federal government and the states. The federal government's share of Medicaid spending-which is determined by the FMAP-is based on states' per capita income and ranges from 50 to 78 percent in FY 2021.100

States have to meet several conditions to be eligible for the increased matching funds, including covering testing and treatments for COVID-19 without imposing any cost-sharing, and not imposing more restrictive Medicaid eligibility standards or procedures, increasing

2020), https://www.axios.com/health-care-bailout-fund-coronavirus-175-billion -361923f7-e5bb-4fb0-9117-1d0a3c759c0d.html [https://perma.cc/7BHB-VBB5].

97. See Karyn Schwartz \& Anthony Damico, Distribution of CARES Act Funding Among Hospitals, KAISER FAMILY Found. (May 13, 2020), https://www.kff.org/health -costs/issue-brief/distribution-of-cares-act-funding-among-hospitals/ [https:// perma.cc/ZN7Z-T2W7]; Jesse Drucker, Jessica Silver-Greenberg, \& Sarah Kliff, Wealthiest Hospitals Got Billions in Bailout for Struggling Health Providers, N.Y. TimEs (May 25, 2020), https://www.nytimes.com/2020/05/25/business/coronavirus-hospitals -bailout.html [https://perma.cc/H7AN-H2VG]; Jay Hancock, Phil Galewitz, \& Elizabeth Lucas, Furor Erupts: Billions Going to Hospitals Based on Medicare Billings, Not COVID19, KAISER HEALTH NEWS (Apr. 10, 2020), https://khn.org/news/furor-erupts-billions -going-to-hospitals-based-on-medicare-billings-not-covid-19/ [https://perma.cc/ RN8N-KRSK].

98. See Pragya Kakani, Amitabh Chandra, Sendhil Mullainathan, \& Ziad Obermeyer, Allocation of COVID-19 Relief Funding to Disproportionately Black Counties, 324 JAMA 1000 (2020), https://jamanetwork.com/journals/jama/fullarticle/ 2769419\#: :text=Disproportionately\%20Black\%20counties\%20(29.6\%25\%20 Black,\%2B0.50\%20SD\%2C\%20P\%20\%3C\%20. [https://perma.cc/ZAH4-MTPR].

99. Families First Coronavirus Response Act, $\S 6008$.

100. MaryBeth Musumeci, Key Questions About the New Increase in Federal Medicaid Matching Funds for COVID-19, KAISER FAMILY Found. (May 4, 2020), https://www .kff.org/coronavirus-covid-19/issue-brief/key-questions-about-the-new-increase-in -federal-medicaid-matching-funds-for-covid-19/ [https://perma.cc/K7PM-Y7WM]. 
premiums, or involuntarily disenrolling beneficiaries who were enrolled as of March 18, 2020 or after through the end of the public health emergency. ${ }^{101}$ The increased FMAP does not apply to administrative expenses or to most Medicaid spending that is already subject to a higher match, including the ACA's Medicaid expansion population. ${ }^{102}$

\section{UnEMPLOYMENT InSURANCE AND OTHER Job-RELATED ASSISTANCE}

Although not specifically targeting low-income individuals, the Families First and CARES Acts expanded job-loss and paid leave protections during the pandemic, providing vital support to low-income households.

Starting with direct support, the CARES Act temporarily expanded federal unemployment insurance (UI) benefits for those who lost their jobs due to the COVID-19 pandemic. The expansion provided an additional federally funded $\$ 600$ per week payment through July $31,2020 .{ }^{103}$ The federal law also encouraged states to provide benefits to workers who have lost hours, even if they retain some employment, by covering some or all of such payments through December 31, 2020.104 This incentive should help workers in the approximately 20 states that do not provide unemployment support to workers who lose hours. ${ }^{105}$ To support "gig workers" and other non-employee workers who would otherwise be excluded from UI programs, the CARES Act provided a set amount of federally funded unemployment compensation for self-employed workers through the end of 2020.106 The rapid enactment, breadth, and complexity of the UI expansions led to rollout problems, with many applicants unable to complete the burdensome application process and others experiencing long delays in

101. Families First Coronavirus Response Act, $\S 6008$. In late October 2020, the Trump Administration issued an interim final rule that would weaken this "continuous coverage" protection for Medicaid beneficiaries. 42 C.F.R. $\$ 433.400$. See Edwin Park, New CMS Rule Would Weaken Families First Continuous Coverage Protection in Medicaid, Geo. Univ. Health Pol'y InSt. CTR. For Children and Families (Nov. 2, 2020), https://ccf.georgetown.edu/2020/11/02/new-cms-rule-would-weaken-families -first-continuous-coverage-protection-in-medicaid/ [https://perma.cc/GUH3-G7LG].

102. Musumeci, supra note 100.

103. CARES Act $\S 2104$.

104. CARES Act $\S \S 2108,2109$.

105. Id.

106. CARES Act $§ 2102$; U.S. Dept. Of Labor, Unemployment Insurance Program Letter No. 16-20 (Apr. 5, 2020), https://wdr.doleta.gov/directives/attach/UIPL/UIPL_ 16-20.pdf [https://perma.cc/KV7N-YLGT] (providing guidance on the Pandemic Unemployment Assistance (PUA) Program to state unemployment agencies). 
receiving benefits. ${ }^{107}$

The July 31 st expiration of the $\$ 600$ supplemental unemployment benefit came just as states faced mid-summer virus surges, leaving many unemployed individuals unable to pay their bills. ${ }^{108}$ Reinstating the supplement was a major sticking point in Congressional negotiations over subsequent response bills. The Trump Administration again undertook unilateral action, authorizing FEMA to provide states with an additional $\$ 300$ per week for unemployed individuals. ${ }^{109}$ The application process was complex, and the amount of funding authorized-\$44 billion-provided additional support for only six weeks. ${ }^{110}$ Researchers have found that the poverty rate increased from May to September following the expiration of the CARES Act's stimulus checks and supplemental unemployment benefit.111

In addition to expanded unemployment benefits, the CARES Act enacted several programs designed to incentivize employers to maintain their existing workforces. One was a forgivable loan administered through the Small Business Administration, called the Paycheck Protection Program (PPP). ${ }^{112}$ Businesses with up to 500 employees were able to apply for up to $\$ 10$ million. ${ }^{113}$ The program ended in early August 2020, after more than 5.1 million businesses received support, but with $\$ 1.26$ billion still left undistributed. ${ }^{114}$ Recipients can apply

107. Zipperer \& Gould, supra note 34; Long et al., supra note 34; Patricia Cohen \& Tiffany Hsu, 'Sudden Black Hole' for the Economy with Millions More Unemployed, N.Y. TIMES (May 28, 2020), https://www.nytimes.com/2020/04/09/business/economy/ unemployment-claim-numbers-coronavirus.html [https://perma.cc/GP5K-FS93].

108. Ben Casselman, End of $\$ 600$ Unemployment Bonus Could Push Millions Past the Brink, N.Y. TimES (July 24, 2020), https://www.nytimes.com/2020/07/21/business/ economy/coronavirus-unemployment-benefits.html [https://perma.cc/H3FC-GKZD].

109. Memorandum from the White House to the Sec'y of Labor, Sec'y of Homeland Security, the Admin. of the Fed. Emergency Mgmt. (Aug. 8, 2020), https://www. whitehouse.gov/presidential-actions/memorandum-authorizing-needs-assistance -program-major-disaster-declarations-related-coronavirus-disease-2019/ [https:// perma.cc/G357-9YGU].

110. Ron Lieber \& Stacy Cowley, Trump's Directives Were Supposed to Offer Relief. Most May Not., N.Y. Times (Aug. 9, 2020), https://www.nytimes.com/2020/08/09/ business/trump-executive-orders-unemployment.html [https://perma.cc/DX6V -JUSW]; Jeff Stein \& Eli Rosenberg, Trump’s $\$ 300$ Unemployment Funding is Already Running Out, Leaving Millions in Crisis Again, WASH. PosT (Sept. 11, 2020), https:// www.washingtonpost.com/us-policy/2020/09/11/lost-wages-unemployment -assistance-expiring/ [https://perma.cc/3DV9-HHHJ].

111. See Parolin et al., supra note 39.

112. CARES Act, $\S 1102$.

113. Id.

114. Sarah D. Wire, A Revamped PPP Coronavirus Loan Program Is in the Works. Will It Help Small Businesses Left out Before?, L.A. TIMES (Aug. 12, 2020), https:// 
for the loan to be forgiven, provided that at least 75 percent of the loan proceeds were used for payroll costs, among other eligibility requirements. ${ }^{115}$ The second employment incentive is a tax credit equal to 50 percent of qualified wages up to $\$ 10,000$ per employee per calendar quarter. ${ }^{116}$ These two workforce incentives are mutually exclusivethat is, employers can only receive one.

Serious inequities have plagued the distribution of PPP loans, with significant funds going to large businesses like global hotel and restaurant chains (which qualify because a single location is deemed a "small business"). ${ }^{117}$ Several large companies returned funds in the wake of public disapprobation. ${ }^{118}$ Additionally, by delivering funds through commercial banks, distribution of PPP loans reflected existing race-related lending gaps. ${ }^{119}$ There is growing evidence that Black business owners had a more difficult time securing funding. ${ }^{120} \mathrm{~A} \mathrm{sec}-$ ond wave of PPP funding, if approved by Congress, may address some of these concerns. ${ }^{121}$

In addition to job-loss support, the Families First Act expanded paid leave protections for employees, requiring certain employers to provide two weeks of paid sick leave at full pay if an employee is sick or quarantined due to COVID-19 and up to twelve weeks of paid leave at two-thirds of the employee's regular pay to care for a child whose school or daycare has closed due to the pandemic. ${ }^{122}$ These

www.latimes.com/politics/story/2020-08-12/rtevamped-ppp-coronavirus-loan -program-is-in-the-works-will-it-help-small-businesses-left-out-before [https:// perma.cc/C63R-W5S5].

115. CARES Act $\S \S 1102,1106$.

116. CARES Act $\S 2301$.

117. Danielle Kurtzleben, Jim Zarroli, Laura Sullivan, Cheryl W. Thompson, Bill Chappell, Graham Smith, \& Pallavi Gogoi, Here's How the Small Business Loan Program Went Wrong in Just 4 Weeks, NPR (May 4, 2020), https://www.npr.org/2020/05/04/ 848389343/how-did-the-small-business-loan-program-have-so-many-problems-in -just-4-weeks [https://perma.cc/G6HY-9SEC].

118. Thomas Franck, Companies Returned \$30 Billion in Small-Business Loans from Paycheck Protection Program, CNBC (Jul. 6, 2020), https://www.cnbc.com/2020/07/ 06/companies-returned-30-billion-in-small-business-loans-from-ppp.html [https:// perma.cc/Z9BH-6BWT].

119. Kramer Mills \& Battisto, supra note 36, at 6.

120. Emily Flitter, Black Business Owners Had a Harder Time Getting Federal Aid, a Study Finds, N.Y. TimeS (Jul. 15, 2020), https://www.nytimes.com/2020/07/15/ business/paycheck-protection-program-bias.html [https://perma.cc/V3X8-QTSS].

121. Wire, supra note 114.

122. See Families First Coronavirus Response Act: Employee Paid Leave Rights, DEP'T OF LABOR (Mar. 2020), https://www.dol.gov/agencies/whd/pandemic/ffcra -employee-paid-leave [https://perma.cc/5LY3-5J3D]. Note that employees that have been employed for less than 30 days are only eligible for two weeks of paid leave to 
provisions, which expire in December 2020, apply to certain public employers and private employers with fewer than 500 employees. ${ }^{123}$ They do not cover independent contractors or most "gig workers." ${ }^{24}$

\section{BUILDING ON THE PANDEMIC RESPONSE: SUSTAINED SUPPORT FOR LOW-INCOME AMERICANS}

Whether the COVID-19 crisis lasts months or years, the initial bipartisan support for significant increases in spending on social welfare programs will abate. Members of Congress and policymakers at all levels of government will be confronted with the choices of which temporary changes should be made permanent, either through statute or by rule. This Part begins by looking at which time-limited measures should be extended beyond the current crisis or augmented. It concludes by discussing what anti-poverty proposals policymakers should consider that go beyond improving existing programs.

\section{A. Which Pandemic Policy Changes to Extend or Augment}

This Section identifies how Congress and federal agencies should build on the pandemic response by making some of the temporary policy changes permanent and further strengthening these safety net programs. We proceed with a focus on food assistance, medical assistance, unemployment insurance, and paid leave.

\section{Food Assistance}

Currently, SNAP monthly benefits do not cover a family's food budget. Households redeem 80 percent of SNAP benefits within just two weeks of receiving them. ${ }^{125}$ Congress should increase maximum SNAP benefits by 15 percent, just as it did in response to the 2008 financial crisis. That increase has been shown to have had a powerful impact, not just for families, but for the national economy. ${ }^{126}$ Congress

care for a child whose school or daycare has closed. Id.

123. Id. Small businesses with fewer than 50 employees can apply for an exemption from the extended family leave requirements. Id.

124. Id.

125. Jared Bernstein \& Ben Spielberg, Preparing for the Next Recession: Lessons from the American Recovery and Reinvestment Act, CTR. ON BUDGET \& POL'Y PRIORITIES (2016), https://www.cbpp.org/research/economy/preparing-for-the-next-recession -lessons-from-the-american-recovery-and [https://perma.cc/9SU6-WRDL].

126. Alan S. Blinder \& Mark Zandi, The Financial Crisis: Lessons for the Next One, CTR. ON BUDGET \& POL'Y PRIORITIES (2015), https://www.cbpp.org/research/ economy/the-financial-crisis-lessons-for-the-next-one [https://perma.cc/L3WP 
should also go beyond merely pausing the Trump Administration's already-enjoined SNAP time limit for ABAWD recipients. Congress should repeal the ABAWD provision. ${ }^{127}$ Congress should also suspend the implementation of the proposed categorical eligibility and utility calculation rules. ${ }^{128}$ Congress should also extend the timeframe for the U.S. Department of Agriculture to spend down the emergency appropriations for the WIC and TEFAP nutrition programs. If either appropriation is exhausted, Congress should consider an additional appropriation for another six-month period. Congress should also extend the Pandemic EBT program through FY 2021 so children who experience school closures later this school year do not go without meals.

When COVID-19 hit, many Americans began ordering their groceries online for the first time (and continue to do so).129 The over forty million Americans who purchase food using SNAP could not. 130 Congress should allow SNAP recipients to purchase groceries online. ${ }^{131}$ The Food and Nutrition Service (FNS) recently launched an online purchasing pilot. Forty-four states and DC are currently participating. ${ }^{132}$ FNS should promulgate a rule that permits SNAP recipients to make purchases online until Congress can make that change legislatively, perhaps in the next Farm Bill.

\section{Medical Assistance}

Congress should provide additional FMAP increases beyond the

-HQSG].

127. 7 U.S.C. $\$ 2011$ (2015).

128. See supra notes 68-76 and accompanying text.

129. Nathaniel Popper, Americans Keep Clicking to Buy, Minting New Online Shopping Winners, N.Y. TIMES (May 13, 2020), https://www.nytimes.com/interactive/ 2020/05/13/technology/online-shopping-buying-sales-coronavirus.html [https:// perma.cc/85ES-HAKV] (reporting data from "several surveys [that] more than a third of all Americans have ordered groceries online for the first time over the last month, and people have spent more ordering groceries online each succeeding week of the crisis.").

130. Retailer Requirements to Provide Online Purchasing to SNAP Households, FOOD \& NuTRIT. SERV. (May 6, 2020), https://www.fns.usda.gov/snap/retailer-requirements -provide-online-purchasing [https://perma.cc/3NJJ-J87K].

131. Abigail Abrams, Mothers Who Rely on Federal Food Aid Struggle to Get Groceries Safely During the COVID-19 Outbreak, Time (June 1, 2020), https://time.com/ 5844953/wic-online-groceries-coronavirus/ [https://perma.cc/NEW5-A8FM].

132. FNS Launches the Online Purchasing Pilot, FoOD \& NuTRIT. SERV. (last updated Dec. 2, 2020) https://www.fns.usda.gov/snap/online-purchasing-pilot [https:// perma.cc/E8FS-Y5S7]. Notably, Amazon and Wal-Mart, are by far the most common participants across the pilot states. See id. 
6.2 percentage point increase in the Families First Act. ${ }^{133}$ As it stands, the Families First FMAP increase is insufficient to offset the state budget shortfalls that would result from even a 1 percentage point increase in unemployment. ${ }^{134}$ Notably, the Families First FMAP increase is smaller than the increase that Congress authorized in the 2009 American Recovery and Reinvestment Act (ARRA), ${ }^{135}$ despite the fact that increases in Medicaid enrollment are likely to be greater during the current pandemic than they were during the Great Recession, and state budget deficits are likely to be more severe. ${ }^{136}$ Congress should also extend the FMAP increase-along with the associated eligibility requirements for states-beyond the end of the public health emergency, since the economic crisis caused by the pandemic seems likely to outlast the pandemic itself, and should increase the Medicaid expansion federal match to 100 percent to encourage more states to expand their Medicaid programs. ${ }^{137}$

The temporary changes in the regulations and reimbursement rules governing telehealth have the potential to improve access to health care (especially for people with chronic conditions or those who live far from health care centers), ${ }^{138}$ but have also raised

133. Sharon Parrott, Aviva Aron-Dine, Michael Leachman, Chad Stone, Dorothy Rosenbaum, LaDonna Pavetti, Peggy Bailey, Chuck Marr, \& Kathleen Romig, Immediate and Robust Policy Response Needed in Face of Grave Risks to the Economy, CTR. BUDGET \& POL'Y PRIORITIES 1, 5-6 (Mar. 19, 2020), https://www.cbpp.org/sites/default/files/ atoms/files/3-19-20econ.pdf [https://perma.cc/YH7D-8QNR].

134. Id.

135. Edwin Park, Critical Need for Further, Large FMAP Increases to Sustain State Medicaid Programs During Economic Crisis, Geo. Univ. Health Pol'y INST. CTR. FOR CHILDREN AND FAMILIES (May 4, 2020), https://ccf.georgetown.edu/2020/05/04/ critical-need-for-further-large-fmap-increases-to-sustain-state-medicaid-programs -during-economic-crisis/ [https://perma.cc/9FD2-KNNJ] (explaining that although ARRA also authorized a minimum FMAP increase of 6.2 percentage points, it also included a "hold harmless" provision that prevented scheduled FMAP reductions and provided for additional FMAP increases based on state unemployment rates-so that the resulting total FMAP increases ranged from 6.94 to 13.87 percentage points). See also Alison Mitchell, Cong. Res. SERV., R46346 MEdiCAid ReCESSion-RElated FMAP INCREASES (2020) (explaining the similarities and differences among FMAP increases in response to the 2001 recession, the 2007-2009 recession, and the 2020 pandemic).

136. Id.

137. See Nicole Huberfeld, Sarah H. Gordon, \& David K. Jones, Federalism Complicates the Response to the COVID-19 Health and Economic Crisis: What Can Be Done?, 45 J. HEALTH PoL., POL'Y, \& L. 11-12 (forthcoming 2020); Parrott et al., supra note 133, at 5-6.

138. See Gabriel Scheffler, Unlocking Access to Health Care: A Federalist Approach to Reforming Occupational Licensing, 29 HEALTH MATRIX 293, 315-16 (2019). 
concerns about fraud, privacy, and quality of care. ${ }^{139}$ Some of the recent changes, such as the loosening of licensing restrictions to enable out-of-state health care providers to deliver health care in-state without obtaining a separate state license, should be made permanent in our view. ${ }^{140}$ But others, such as payment parity, have more complex trade-offs and will require further study and analysis. ${ }^{141}$

\section{Unemployment Insurance}

Even before the pandemic, the need to reform and update UI systems was clear. Over the last fifteen years, UI has covered a smaller and smaller slice of the U.S. labor force as states have tightened eligibility requirements and reduced the duration of benefits. ${ }^{142}$ States have also severely underfunded their UI trust funds, and no state sufficiently assists UI recipients in searching for a new job. ${ }^{143}$ Indeed, many of the UI provisions in the CARES Act can be traced to reformers' pre-COVID wish lists. ${ }^{144}$ Rather than returning to the old, flawed system once the crisis is over, recent reforms offer an opportunity to permanently improve UI and make it work for today's economy.

Since the 2008 recession, "nontraditional" jobs have dominated job-growth figures, reflecting economy-wide shifts toward part-time,

139. See Carmel Schachar, Jaclyn Engel, \& Glyn Elwyn, Implications for Telehealth in a Postpandemic Future: Regulatory and Privacy Issues, 323 JAMA 2375, 2376 (May 18, 2020), https://jamanetwork.com/journals/jama/fullarticle/2766369 [https://perma.cc/8H3F-8HDB]; Fred Schulte, Coronavirus Fuels Explosive Growth in Telehealth - And Concern About Fraud, KAISER HEALTH NEws (Apr. 22, 2020), https:// khn.org/news/coronavirus-fuels-explosive-growth-in-telehealth-\%E2\%80\%95-and -concern-about-fraud/ [https://perma.cc/78NU-SGGH].

140. See Alexa Richardson, Medical Licensure Law Suspensions During COVID-19 Present Opportunity for Change, HARV. L. SCH. PETRIE-Flom CTR.: BiLl OF HEALTH (Apr. 23, 2020), https://blog.petrieflom.law.harvard.edu/2020/04/23/medical-licensure -laws-covid19/ [https://perma.cc/W84B-UKMH]. See also Robert Kocher, Topher Spiro, Emily Oshima Lee, Gabriel Scheffler, Stephen Shortell, David Cutler, \& Ezekiel Emanuel, Doctors Without State Borders: Physicians Practicing Across State Lines, HEALTH AFF. Blog (Feb. 18, 2014), http://healthaffairs.org/blog/2014/02/18/ doctors-without-state-borders-practicing-across-state-lines [https://perma.cc/8UMG -4 VUS].

141. See Schachar, Engel, \& Elwyn, supra note 139, at 2376.

142. See, e.g., Jason Furman, Chairman, Council of Econ. Advisers, The Economic Case for Strengthening Unemployment Insurance, at the Center for American Progress, Washington, D.C. 9 (July 11, 2016), https://obamawhitehouse.archives.gov/sites/ default/files/page/files/20160711_furman_uireform_cea.pdf [https://perma.cc/ Z7YK-L3RS].

143. Id. at $10-11$.

144. Id. 
temporary, and nonemployee worker relationships. ${ }^{145}$ Unemployment insurance systems have left many of these workers without protection, undermining the systems' ability to act as a safety net during recessions. The CARES Act expands coverage for freelance and selfemployed workers, as well as workers who lose hours while retaining their jobs. These expansions should be made permanent. If funding is a concern, states or the federal government can increase the base wage to which UI applies, which is currently $\$ 7,000$ and is not indexed for inflation, leaving room for upward growth. ${ }^{146}$

\section{Paid Leave}

As with unemployment insurance, the reforms to paid leave policies made in response to the pandemic have been sorely needed ${ }^{147}$ and should be extended beyond the current crisis. Low-wage workers should not be forced to choose between paying their bills and caring for themselves and their children. ${ }^{148}$ Moreover, incentivizing people to work when they are sick spreads infection and puts others at risk. ${ }^{149}$ Congress should make permanent the paid leave mandates in the Families First Act, and should expand the mandate to cover more types of employers. ${ }^{150}$

\section{B. The Safety Net After the Pandemic: The Long View}

One limitation of crisis-induced social policy is that legislators prioritize policies that can be implemented quickly over policies that

145. Id. at 4 .

146. Id. at 10 (proposing the same).

147. Elise Gould, Rich People Have Paid Sick Days. Poor People Do Not., Econ. Pol'Y INST. (Jan. 15, 2015), https://www.epi.org/publication/rich-people-have-paid-sick -days-poor-people-do-not/ [https://perma.cc/L4TC-A83Y].

148. Lisa Clemens-Cope, Cynthia D. Perry, Genevieve M. Kenney, Jennifer E. Pelletier, \& Matthew S. Pantell, Access to and Use of Paid Sick Leave Among Low-Income Families with Children, 122 PEDIATRICS e480 (2008).

149. Supriya Kumar, The Impact of Workplace Policies and Other Social Factors on Self-Reported Influenza-Like Illness Incidence During the 2009 H1N1 Pandemic, 102 AM. J. Pub. HEAlth e1 (2011), https://www.cdc.gov/cpr/documents/science/AJPH 2011_300307v1.pdf [https://perma.cc/LZ7H-2PFU] (estimating that an additional 5 million people contracted the H1N1 influenza virus during the 2009 pandemic due to inadequate workplace protections such as the absence of paid sick leave); Diana Boesch, Sarah Jane Glynn, \& Shilpa Phadke, Lack of Paid Leave Risks Public Health During the Coronavirus Outbreak, CTR. FOR AM. PROGRESS (Mar. 12, 2020), https://www .americanprogress.org/issues/women/news/2020/03/12/481609/lack-paid-leave -risks-public-health-coronavirus-outbreak/ [https://perma.cc/66FQ-KTKQ].

150. For a comprehensive proposal, see Deborah Widiss, Equalizing Parental Leave, 105 MinN. L. REv. (forthcoming 2021). 
might be better across other dimensions. Yet urgency does not obviate the need for transformational change. Congress and the Biden administration should seize this unique moment to consider how to transform our safety net into one that meaningfully supports all Americans.

This Section suggests some changes that are not animated strictly by a desire for rapid relief to low-income Americans. In particular, we recommend policies that begin to dismantle the racism embedded in American social policy ${ }^{151}$ and that reject the insensitive and unrealistic demands of work-based social benefits.

\section{The United States Needs Universal Health Insurance Coverage}

The pandemic has underscored the necessity of having a health insurance program that is both affordable and open to everyone. It has also underscored the precarious nature of employer-based health insurance coverage: because of this system, millions of Americans will lose their health insurance coverage just at a time when they are especially financially vulnerable. ${ }^{152}$ Although some people who lose coverage during the pandemic may be eligible for coverage through Medicaid or for subsidized coverage on the ACA exchanges, many others will have no affordable option to obtain health insurance. ${ }^{153}$ Moreover, even those who have insurance coverage may be unable to pay the out-of-pocket costs associated with COVID-19 treatment and may decide as a result to risk not seeking medical care, thereby endangering their own health. ${ }^{154}$

President-elect Biden has proposed a plan that would lower the Medicare eligibility age to 60, expand the subsidies on the ACA exchanges, and create a new public option that would compete with

151. For a discussion of how applying an anti-racism perspective would change progressive policy proposals, see IBRAM X. KENDI, How To BE AN ANTI-RACIST 21-23 (2019). For a related inquiry into how a focus on how people experience public benefits programs could change law and policy, see Monica Bell, Stephanie Garlock, \& Alexander Nabavi-Noori, Toward a Demosprudence of Poverty, 69 DUKE L.J. 1473 (2020).

152. Ezra Klein, It's Time to Move Past Employer-Based Health Insurance, Vox (Apr. 9, 2020), https://www.vox.com/2020/4/9/21210353/coronavirus-health-insurance -biden-sanders-medicare-for-all [https://perma.cc/72DK-6UA6].

153. Id.

154. See generally Zarek C. Brot-Goldberg, Amitabh Chandra, Benjamin R. Handel, \& Jonathan T. Kolstad, What Does a Deductible Do? The Impact of Cost-Sharing on Health Care Prices, Quantities, and Spending Dynamics, 132 QUART. J. ECON. 1261 (2017) (finding that a switch to high-deductible plans caused enrollees to reduce health care spending across the board, including on both potentially valuable and potentially wasteful care). 
private insurers. 155 Congressional Democrats have also introduced a number of bills that would expand the government's role in providing health insurance, ranging from Medicare-for-All to "public option" proposals. ${ }^{156}$ Other recent bills would provide for a temporary coverage expansion during the pandemic, using either Medicare or Medicaid to cover the costs of COVID-19-related treatment and testing. ${ }^{157}$

\section{Federal Policymakers Should Streamline Medicaid, SNAP, and UI}

According to the Congressional Budget Office, SNAP, Medicaid, and UI provide the majority of the federal government's automatic stabilization spending. ${ }^{158}$ Yet, more should be done to enhance how these programs respond to future crises. SNAP has uniform benefit levels, but the federal government could do more to streamline other features of the program, like joint processing with Medicaid, simplified reporting, and longer certification periods for the elderly and people with disabilities. ${ }^{159}$ Likewise, policymakers should do more to promote enrollment in Medicaid and subsidized private coverage on the ACA exchanges, for instance by broadening the use of presumptive eligibility and streamlining coverage enrollment with UI processes. ${ }^{160}$

155. Health Care, JOE BIDEN FOR PRESIDENT, https://joebiden.com/healthcare/ [https://perma.cc/F7ZQ-V6BT]; Joe Biden, Joe Biden Outlines New Steps to Ease Economic Burden on Working People, https://medium.com/@JoeBiden/joe-biden-outlines-new-steps-to-ease-economic-burden-on-working-people-e3e121037322 [https://perma.cc/K4YL-FDBA].

156. Compare Medicare-for-all and Public Plan Proposals, KAISER FAMILY FOUND. (May 15, 2019), https://www.kff.org/interactive/compare-medicare-for-all-public -plan-proposals/ [https://perma.cc/GN6M-ASBE].

157. Health Care Emergency Guarantee Act, H.R. 6906 116th Cong. (2020); Emergency Medicaid for Coronavirus Treatment Act H.R. 6462 116th Cong. (2020).

158. Frank Russek \& Kim Kowalewski, How CBO Estimates Automatic Stabilizers: Working Paper 2015-07, Cong. BuDGET OFFICE. Automatic stabilization refers to increased government spending during an economic downturn that does not require new legislation or regulations.

159. For some promising proposals, see Hilary Hoynes \& Diane Whitmore Schanzenbach, Policies to Strengthen Our Nation's Supplemental Nutrition Assistance Program, WASH. CTR. FOR EQUITABLE GROWTH (Feb. 18, 2020), https://equitablegrowth .org/policies-to-strengthen-our-nations-supplemental-nutrition-assistance -program/ [https://perma.cc/D5CE-GHFW]. See also State Options Report, FooD \& NUTRIT. SERV. (14th ed.) (May 2018), https://fns-prod.azureedge.net/sites/default/ files/snap/14-State-Options.pdf [https://perma.cc/5VD2-NFMM].

160. See Christen Linke Young \& Sobin Lee, Making ACA Enrollment More Automatic for the Newly Unemployed, USC-BROOKINGS SCHAEFFER INITIATIVE FOR HEALTH POL'Y (May 2020), https://www.brookings.edu/wp|-content/uploads/2020/05/Young-and -Lee_May_2020-1.pdf [https://perma.cc/682L-E3FE]; Parrott et al., supra note 133, at 6-7. 
Congress should also extend SNAP and Medicaid to Americans who live in overseas territories so that their access to basic assistance does not turn on whether or not Congress will make an emergency appropriation every time there is a national crisis. ${ }^{161}$

The pandemic has also highlighted the importance of adding automatic stabilizers to Medicaid, SNAP, and UI. ${ }^{162}$ Each of these three programs are countercyclical, meaning that enrollment tends to increase when the economy weakens, and to decrease when the economy grows stronger. ${ }^{163}$ This presents budgetary challenges for states during economic downturns, since their spending on Medicaid and UI tends to increase just as their tax revenue decreases, and since they must balance their budgets annually. ${ }^{164}$ For Medicaid, states tend to respond by making eligibility requirements more stringent, reducing the scope of covered benefits, and reducing the amount that they pay providers-limiting essential health benefits to low-income groups when they are especially vulnerable. ${ }^{165}$ Instead of relying on Congress to increase FMAP or expand UI benefits every time the United States experiences an economic downturn, a better approach would be to automatically increase federal funding to Medicaid, CHIP, and UI programs any time a state's unemployment rate exceeds a threshold level. 166 This approach would protect vulnerable populations during economic crises by preventing states from making harmful cuts, and would be administratively simpler and faster. ${ }^{167}$ Congress could similarly improve SNAP's ability to serve as an automatic stabilizer by increasing the maximum benefit by 15 percent whenever the national unemployment rate triggers the Sahm recession indicator. ${ }^{168}$ Enacting

161. See supra note 66 and accompanying text.

162. See Matthew Fiedler, States Are Being Crushed by the Coronavirus. Only This Can Help., N.Y. Times (Apr. 22, 2020), https://www.nytimes.com/2020/04/22/ opinion/coronavirus-states-budgets.html [https://perma.cc/L8CJ-S69T].

163. Alison Mitchell, CoNG. RES. SERV., R46346 MEDiCAID RECESSION-RELATEd FMAP INCREASES (2020).

164. Matthew Fiedler, Jason Furman, \& Wilson Powell III, Increasing Federal Support for State Medicaid and CHIP Programs in Response to Economic Downturns, BROOKINGS INST. (2020), https://www.brookings.edu/research/increasing-federal -support-for-state-medicaid-and-chip-programs-in-response-to-economic -downturns/ [https://perma.cc/8ENB-P88W].

165. Id. at $99-100$.

166. See id. (proposing such an approach for Medicaid and CHIP). See also Li Zhou \& Ella Nilsen, Congress Should Consider These 7 Ideas for the Next Stimulus Package, Vox (May 18, 2020), https://www.vox.com/2020/5/18/

21246421/congress-stimulus-ideas [https://perma.cc/PNT8-P9PF].

167. Id.

168. For such a proposal, see Hilary Hoynes \& Diane Whitmore Schanzenbach, 
such automatic expansions would enable federal and state agencies to act more quickly, with greater certainty of federal support for expanded benefits in times of need. Furthermore, Congress should protect SNAP from inadequate funding or a government shutdown by making two changes in its appropriations process. Congress should fund SNAP via an advance appropriation and include a provision that provides "such sums as may be necessary" to fulfill federal law. 169

\section{Congress Should Legislate a Permanent Child Allowance}

The CARES Act recovery rebate check, by providing a $\$ 500$ payment for each child, suggests what a Universal Child Allowance might look like. A child allowance is similar in concept to a universal basic income ${ }^{170}$ but provided to children only (or, more accurately, their parents or guardians). Congress and the Biden administration should seriously consider enacting such a policy, which has been proposed time and again by policymakers and experts. ${ }^{171}$

Currently, low-income families may receive cash support via refundable tax credits, specifically, the earned income tax credit (EITC) and child tax credit, ${ }^{172}$ and some may be eligible for Temporary Aid to Needy Families (TANF) as well. For the most part, only working families are eligible for these benefits. ${ }^{173}$ While the work-incentive

Strengthening SNAP as an Automatic Stabilizer, BRoOKINGS INST., https://www .hamiltonproject.org/assets/files/HoynesSchanzenbach_web_20190506.pdf [https:// perma.cc/B572-RT2K].

169. Incidentally, Medicaid funding already enjoys these two protections. See Richard Kogan, Dottie Rosenbaum, \& Zoë Neuberger, Protecting SNAP and Child Nutrition Programs from Appropriations Lapses, ${ }^{* *} 3-4$ CTR. ON BUDGET \& POL'Y PRIORITIES (July 22, 2020), https://www.cbpp.org/research/food-assistance/protecting-snap-and-child -nutrition-programs-from-appropriations-lapses [https://perma.cc/5LHQ-T98T].

170. For various discussions of basic income proposals, see, e.g., Miranda Perry Fleischer \& Daniel Hemel, The Architecture of a Basic Income, 87 U. CHI. L. REV. 625 (2020); Brishen Rogers, How Not To Argue for a Basic Income, Boston Rev. (Oct 31, 2016).

171. E.g. Young Child Tax Credit Act, H.R. 4693 (proposing a fully refundable tax credit of $\$ 1,500$ for each child under age three, available to households with no earnings or very low earnings); Samuel Hammond \& Robert Orr, Toward a Universal Child Benefit, NISKANEN CTR. (2016), https://www.niskanencenter.org/wp-content/ uploads/old_uploads/2016/10/UniversalChildBenefit_final.pdf [https://perma.cc/ E3MQ-Y595] (proposing consolidating all child-related tax benefits into one universal credit of $\$ 2000$ per minor child, again, irrespective of low earnings).

172. I.R.C. $\S \S 32,24$ (West 2019).

173. Taylor LaJoie, The Child Tax Credit: Primer, TAX Found. (2020), https:// files.taxfoundation.org/20200413132740/Child-Tax-Credit-A-Primer.pdf [https:// perma.cc/95UT-7GFR]; Policy Basics: The Earned Income Tax Credit, CTR. ON BUDGET \& POL'y PRIORITIES (2019), https://www.cbpp.org/sites/default/files/atoms/files/ 
structure is politically popular, the result is that the poorest families, those with unstable ties to the labor market, receive less support or none at all. ${ }^{174}$

A child allowance would obviate these concerns by providing a flat benefit to all families with children, usually at a set amount per child. Such a structure would eliminate any concerns about work disincentives and benefit gaps for the poorest families and would be administratively much simpler than both means-tested and work-based programs. The benefit could be provided monthly or annually and, if large enough, could drastically reduce administrative costs by replacing the EITC, child tax credit, and TANF. The benefit could phase out at higher income levels, similar to the recovery rebate, or be offset by a higher tax rate among higher-income households.

4. The United States Can No Longer Permit Racism to Serve as an Organizing Principle of its Safety Net

Federal law has consistently embraced racism and xenophobia in its organization of social welfare programs. From the New Deal ${ }^{175}$ to the War on Poverty ${ }^{176}$ to Welfare Reform, ${ }^{177}$ American policymakers have repeatedly excluded African-Americans, indigenous Americans, Americans who live in overseas territories, and immigrants from the programs discussed in this Essay. Black Americans are routinely singled out as unworthy of government programs. ${ }^{178}$ Indigenous

policybasics-eitc.pdf [https://perma.cc/7U3J-FXJW]; Policy Basics: Temporary Aid to Needy Families, CTR. ON BudGET \& PoL'Y PRIORITIES 5 (2020), https://www.cbpp.org/ sites/default/files/atoms/files/7-22-10tanf2.pdf [https://perma.cc/8485-GC5B] (describing TANF work requirements).

174. See Ariel Jurow Kleiman, Low-End Regressivity, 72 TAX L. REV. 101 (2018) (making this point); Isaac Shapiro, Robert Greenstein, Danilo Trisi, \& Bryann DaSilva, It Pays to Work: Work Incentives and the Safety Net, CTR. ON BUDGET \& POL'Y PRIORITIES (2016), http://www.cbpp.org/sites/default/files/atoms/files/3-3-16tax.pdf [https://perma.cc/VES6-XC7Y] (finding that the majority of poor households do not receive TANF benefits).

175. See Cybelle Fox, Three Worlds of Relief: Race, Immigration, and the American Welfare State From the Progressive ERa to the NEW DEAL (2012).

176. See Jill Quadagno, The Color of Welfare: HoW RaCism Undermined the War ON POVERTY (1996)

177. See Race And the Politics of Welfare Reform (Sanford F. Schram, Joe Soss, \& Richard C. Fording eds. 2003).

178. Joe Soss, Richard C. Fording, \& SANFord F. SChram, Discipling the Poor: Neoliberal Paternalism And the Persistent Power of RaCe (2011); Alana Semuels, States With Large Black Populations Are Stingier With Government Benefits, THE ATLANTIC (June 6, 2017), https://www.theatlantic.com/business/archive/2017/06/ race-safety-net-welfare/529203/ [https://perma.cc/ET2J-3LKA]. 
Americans are poorly served by a chronically underfunded Indian Health Service and a commodity food distribution program that does not meet the needs of its tribal membership. ${ }^{179}$ Americans who live in Puerto Rico and the other territories may access nutrition and medical assistance, but the federal government provides less funding to the territories than it does to the states, including through a budgetary cap. ${ }^{180}$ And federal and state law renders lawfully present immigrants ineligible for SNAP, Medicaid, the EITC, and other benefits, even in some cases where these adults are raising citizen children. ${ }^{181}$ The Trump Administration's immigration policies and its proposals for SNAP and Medicaid work requirements fit this pattern of earlier policy initiatives and even earlier tropes rooted in slavery and Jim Crow. ${ }^{182}$ This racism has been abetted by the devolved structure of many American social welfare programs permitting states to deny access to members of racial and ethnic minorities. ${ }^{183}$ The three policies we propose above-universal health insurance, streamlining Medicaid, SNAP, and UI, and a child allowance-would make it more difficult for federal, state, and local administrators to discriminate against people of color by reducing discretion and differences in benefit levels and access. But we are not so naïve as to think that they would be sufficient to root out the persistent racism in the American welfare state. Only from sustained mobilization and pressure on policymakers will those changes come.

179. Andrew Siddons, The Never-Ending Crisis at the Indian Health Service, RoLLCALL (March 5, 2018), https://www.rollcall.com/2018/03/05/the-never-ending -crisis-at-the-indian-health-service/ [https://perma.cc/BD89

-MAHM].

180. Brynne Keith Jennings \& Elizabeth Wolkomir, How Does Household Food Assistance in Puerto Rico Compare to the Rest of the United States?, CTR. ON BUDGET \& POL'Y PRIORITIES (Jan. 15, 2020), https://www.cbpp.org/research/food-assistance/how -does-household-food-assistance-in-puerto-rico-compare-to-the-rest-of [https:// perma.cc/P2ZD-HV5L]; Robin Rudowitz, Medicaid Financing Cliff: Implications for the Health Care Systems in Puerto Rico and USVI, KAISER FAMILY Found. (May 21, 2019); see also Andrew Hammond, Americans Outside the Welfare State, 119 MICH. L. REV. (forthcoming 2021).

181. See Andrew Hammond, The Immigration-Welfare Nexus in a New Era?, 22 LEWIS \& CLARK L. REV. 501, 508-18 (2018).

182. See Elisa Minoff, The Racist Roots of Work Requirements, CTR. FOR THE STUDY OF Soc. PoL'Y (Feb. 2020), https://cssp.org/wp-content/uploads/2020/02/Racist-Roots -of-Work-Requirements-CSSP-1.pdf [https://perma.cc/Y2WY-EA9N].

183. See Robert C. Lieberman \& John S. Lapinski, American Federalism, Race, and the Administration of Welfare, 31 BRIT. J. PoLI. SCI. 303 (2001). 


\section{CONCLUSION}

This survey of federal anti-poverty initiatives amid the pandemic is not meant to be exhaustive. ${ }^{184}$ Any national effort to confront the calamities of COVID-19 cannot be limited to these programs. Nor can such an effort ignore them. While other proposals, like universal basic income, are worthy of consideration, they will necessarily require sustained efforts by tenacious national coalitions to overcome the substantial barriers to creating new federal programs, especially in an era of divided government. That does not mean those proposals are not worth fighting for, but in the meantime, we should not neglect the programs discussed above-ones that comprise some of the largest expenditures by the United States that benefit low-income Americans and are providing assistance to millions of Americans at this very moment.

184. Other proposals worthy of consideration include Michelle Layser, Edward W. De Barbieri, Andrew Greenlee, Tracy Kaye, \& Blaine G. Saito, Mitigating Housing Instability During a Pandemic (Univ. of Ill. Coll. Of L. Legal Stud. Res. Paper No. 20-15, 2020), https://papers.ssrn.com/sol3/papers.cfm?abstract_id=3613789 (discussing housing intiatives); Deborah Widiss, Equalizing Parental Leave, 105 MinN. L. REV. (forthcoming 2021) (advocating for national paid family leave); Pamela Foohey \& Sara S. Green, How Government Rules Prevent Poor Americans From Saving, Politico (Sept. 3, 2020), https://www.politico.com/news/agenda/2020/09/03/how-government-keeps -poor-from-saving-407839 [https://perma.cc/4L25-439Q] (criticizing asset rules in safety net programs and promoting national legislation). 